\title{
Receptor density pattern confirms and enhances the anatomic-functional features of the macaque superior parietal lobule areas
}

\author{
Daniele Impieri ${ }^{1} \cdot$ Karl Zilles $^{2,3} \cdot$ Meiqi Niu $^{2} \cdot$ Lucija Rapan $^{2} \cdot$ Nicole Schubert $^{2} \cdot$ Claudio Galletti $^{1}$. \\ Nicola Palomero-Gallagher ${ }^{2,4}$
}

Received: 11 March 2019 / Accepted: 30 July 2019 / Published online: 7 August 2019

(c) The Author(s) 2019

\begin{abstract}
The macaque monkey superior parietal lobule (SPL) is part of a neuronal network involved in the integration of information from visual and somatosensory cortical areas for execution of reaching and grasping movements. We applied quantitative in vitro receptor autoradiography to analyse the distribution patterns of 15 different receptors for glutamate, GABA, acetylcholine, serotonin, dopamine, and adenosine in the SPL of three adult male Macaca fascicularis monkeys. For each area, mean (averaged over all cortical layers) receptor densities were visualized as a receptor fingerprint of that area. Multivariate analyses were conducted to detect clusters of areas according to the degree of (dis)similarity of their receptor organization. Differences in regional and laminar receptor distributions confirm the location and extent of areas V6, V6Av, V6Ad, PEc, PEci, and PGm as found in cytoarchitectonic and functional studies, but also enable the definition of three subdivisions within area PE. Receptor densities are higher in supra- than in infragranular layers, with the exception of kainate, $\mathbf{M}_{2}$, and adenosine receptors. Glutamate and GABAergic receptors are the most expressed in all areas analysed. Hierarchical cluster analyses demonstrate that SPL areas are organized in two groups, an organization that corresponds to the visual or sensorymotor characteristics of those areas. Finally, based on present results and in the framework of our current understanding of the structural and functional organization of the primate SPL, we propose a novel pattern of homologies between human and macaque SPL areas.
\end{abstract}

Keywords Monkey $\cdot$ Neurochemical organization $\cdot$ Posterior parietal cortex $\cdot$ Somatosensory-motor input $\cdot$ Visuo-motor input

\section{Introduction}

Nicola Palomero-Gallagher

n.palomero-gallagher@fz-juelich.de

1 Department of Biomedical and Neuromotor Sciences, University of Bologna, 40126 Bologna, Italy

2 Institute of Neuroscience and Medicine (INM-1), Research Centre Jülich, 52425 Jülich, Germany

3 JARA-BRAIN, Jülich-Aachen Research Alliance, Jülich, Germany

4 Department of Psychiatry, Psychotherapy and Psychosomatics, Medical Faculty, RWTH, Aachen, Germany
The movement of the limbs necessary to reach or grasp objects requires the integration in the cerebral cortex of motor signals with visual and somatosensory stimuli. The brain regions activated during the association of these different sensory-motor modalities to enable the execution of more or less fine movements of the limbs are known as associative cortices.

The superior parietal lobule (SPL) of the macaque monkey is recognized as an associative cortex, as it is part of a neuronal network involved in the association of information coming from frontal and visual cortices useful to plan and control the execution of reaching and grasping movements (Galletti and Fattori 2018; Galletti et al. 2003; Goodale and Milner 1992; Rizzolatti and Matelli 2003). This brain region hosts several cyto- and myelo-architectonically defined areas 
(Colby et al. 1988; Luppino et al. 2005; Pandya and Seltzer 1982; see Fig. 1), some of which to date have also been electrophysiologically extensively investigated, but others much less studied.

Functional and anatomical studies of SPL areas showed that there are two opposite but heavily interconnected flows of information within this structure, a visual one directed caudo-rostrally and a somatosensory one rostro-caudally, with a strong sensory-motor integration in between. Indeed, moving anteriorly from the posterior end of SPL, we find areas V6 (pure visual motion area; Galletti et al. 1999a, 2001; Gamberini et al. 2015), V6Av and V6Ad (visuomotor areas with somatosensory influence from the upper limbs; Galletti et al. 1999b; Gamberini et al. 2009, 2011, 2015, 2018; Passarelli et al. 2011), PEc (visuo-motor area with higher incidence of the somatosensory input from both upper and lower limbs; Bakola et al. 2010; Breveglieri et al., 2006, 2008; Gamberini et al. 2018; Piserchia et al. 2017), and PE (somatosensory-motor area without visual influence; Bakola et al. 2013; Mountcastle et al. 1975; Padberg et al. 2007; Seelke et al. 2012). Other areas seem to have a corollary role in this sensory-motor network, as area PGm is mainly involved in oculomotor activity, spatial navigation (Leichnetz 2001; Olson et al. 1996; Passarelli et al. 2018; Thier and Andersen 1998), and visually guided limb movements (Ferraina et al. 1997; Passarelli et al. 2018), and area

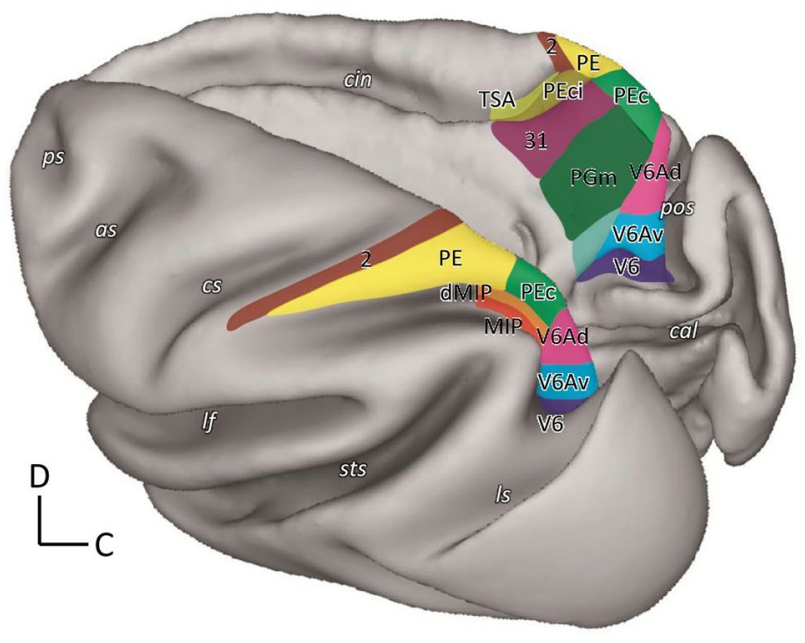

Fig. 1 Location and extent of SPL and adjoining areas in the macaque brain. 3D reconstruction of the left hemisphere (in dorsal view) and of the right one (in mesial view) of a macaque monkey brain obtained using CARET software (http://brainvis.wustl.edu/wiki/ index.php/Caret:Download) showing the location and extent of the areas that compose the SPL, as well as of directly adjacent areas. as arcuate sulcus, cal calcarine sulcus, cin cingulate sulcus, $c s$ central sulcus, ips intraparietal sulcus, If lateral fissure, $l s$ lunate sulcus, $p s$ principal sulcus, pos parieto-occipital sulcus, sts superior temporal sulcus, $C$ caudal, $D$ dorsal
PEci displays sensory-motor properties (Morecraft et al. 2004; Murray and Coulter 1981).

The aim of this work is to define the chemo-architecture of the cortex of the SPL, looking for possible correlations between cytoarchitectonic patterns, chemoarchitectonic organization, and functional segregations of the areas located therein.

\section{Materials and methods}

All the experimental protocols were in accordance with the guidelines of the European laws for the care and use of animals for scientific purposes.

Four hemispheres of three Macaca fascicularis brains were used to collect the data shown in this study (animal ID \#11539, left and right hemispheres; animal ID \#11543, left hemisphere; animal ID \#11530, left hemisphere). All the animals were male specimens between 6 and 8 years old, with a body weight between 5.2 and $6.6 \mathrm{~kg}$, and obtained from Covance Company, Münster, where they were used as control animals for pharmaceutical studies performed in compliance with legal requirements.

\section{Histological procedures}

The animals were killed receiving a lethal dose of sodium pentobarbital (i.v. injection). Then, the brains were removed from the skull, and brain stem and cerebellum were dissected off in close proximity to the cerebral peduncles. The brains were divided into hemispheres cutting the corpus callosum, and then in a rostral and a caudal block making a cut in coronal plane of sectioning between the central and arcuate sulci. The unfixed tissue blocks were frozen in isopentane at -40 to $-50{ }^{\circ} \mathrm{C}$, and then stored in airtight plastic bags at $-70^{\circ} \mathrm{C}$. Each block was then sectioned in the coronal plane using a cryostat microtome (CM 3050, Leica, Germany), obtaining slices of $20 \mu \mathrm{m}$ thickness which were thaw-mounted on gelatine-coated slides and freeze-dried overnight. Alternating sections were stained for cell bodies (Merker 1983) or myelin (Gallyas 1979), or processed for the visualization of neurotransmitter receptor binding sites. Specifically, tissue blocks were serially sectioned in such a way that groups of 25 sections ("repeats") were collected throughout the slab, and 20 sections were discarded between repeats. Repeats consisted of a predetermined order of sections meant for the visualization of a specific receptor type or histological staining. Every 4th and 15th sections of a repeat were used for visualization of cell bodies, and every 9th and 20th sections for the myelin stain. Thus, the distance between two sections processed for the same receptor type was of $900 \mu \mathrm{m}$. At six different rostrocaudal levels throughout the brain, the "repeat" consisted of 46 sections, 
since it also included sections used for the determination of non-specific binding (see below).

\section{Receptor autoradiographic labelling}

Quantitative in vitro receptor autoradiography was applied to label 15 different receptors for the transmitters glutamate (AMPA, kainate, NMDA), GABA $\left(\mathrm{GABA}_{\mathrm{A}}, \mathrm{GABA}_{\mathrm{B}}\right.$, $\mathrm{GABA}_{\mathrm{A}}$ associated benzodiazepine $\left[\mathrm{GABA}_{\mathrm{A}} / \mathrm{BZ}\right]$ binding sites), acetylcholine (muscarinic $\mathrm{M}_{1}, \mathrm{M}_{2}, \mathrm{M}_{3}$ ), noradrenaline $\left(\alpha_{1}, \alpha_{2}\right)$, serotonin $\left(5-\mathrm{HT}_{1 \mathrm{~A}}, 5-\mathrm{HT}_{2}\right)$, dopamine $\left(\mathrm{D}_{1}\right)$, and adenosine $\left(\mathrm{A}_{1}\right)$ by incubating the sections in solutions of respective tritiated ligands according to previously published protocols (Palomero-Gallagher and Zilles 2018; Zilles et al. 2002). Incubation protocols are specified in Table 1. In short, the labelling protocol included a washing step to rehydrate the sections and remove endogenous substances, a main incubation, and a final rinsing step to remove the surplus ligand. In the main incubation, sections were incubated with either a tritiated ligand alone (in nm concentrations) to determine total binding, or with the tritiated ligand (also in $\mathrm{nm}$ concentrations) accompanied by a non-labelled specific displacer (in $\mu \mathrm{m}$ concentrations) to determine the proportion of displaceable, non-specific binding. Specific binding is the difference between total and non-specific binding. Since the ligands and binding protocols used resulted in a displaceable binding, which was less than $5 \%$ of the total binding, we consider total binding to be equivalent of specific binding. The sections processed for receptor autoradiography were then exposed together with plastic samples of known radioactivity against tritium-sensitive films (Hyperfilm, Amersham) for a period of 4-12 weeks based on the ligand used.

\section{Image analysis}

The ensuing autoradiographs were processed by densitometry with a video-based image analysing technique described in previously published studies (Palomero-Gallagher and Zilles 2018; Zilles et al. 2002). Briefly, the autoradiographs were digitized using a CCD camera, and stored as 8-bit grey value images. The plastic scales of known radioactivity were used to create a transformation curve to linearize the autoradiographs, i.e. to transform the grey values in each pixel of the autoradiograph into concentrations of radioactivity in the tissue. These concentrations of radioactivity were then converted into binding-site densities, $B_{\max }$ values (concentration values in $\mathrm{fmol} / \mathrm{mg}$ protein at saturation of the ligand-receptor complex) by multiplying the grey values of the linearized autoradiographs by $\left(K_{\mathrm{D}}+c\right) / c$ (where $K_{\mathrm{D}}$ is a dissociation constant of the ligand-receptor binding kinetics at the equilibrium phase, and $c$ the free concentration of labelled ligand in the incubation buffer). Additionally, linearized autoradiographs were subjected to linear contrast enhancement, colour coding and median filtering for visualization purposes. These final steps were useful to obtain images that could be analysed by visual inspection, to subdivide the SPL into different cortical areas.

The mean areal density value for each area was calculated using in house software (AnaRec), which extracted the mean of the grey values contained in a specific cortical area and transformed it into a receptor concentration per unit protein (fmol/mg protein). To this purpose, and depending on the size of the area, a series of 3-5 equidistantly spaced sections per animal and receptor type were analysed. The ensuing receptor densities were represented as multi-receptor fingerprints, i.e. as polar coordinate plots simultaneously depicting the concentrations of all examined receptor types within a given cortical area. After that, all the data available were analysed to obtain a "receptor fingerprint" for each identified cortical area.

For each identified area, a Grey Level Index (GLI) value was also obtained from sections stained with the Nissl method to quantitatively compare the cytoarchitecture of the areas examined in this study (Wree et al. 1982). This analysis was performed choosing the best cytological segment of each cortical area, where the plane of sectioning was perpendicular to all cortical layers. The GLI, which quantifies the volume of cell bodies relative to the total brain volume, was computed using in-house MATLAB scripts (for further details, see Palomero-Gallagher and Zilles 2018; Zilles et al. 2002).

\section{Statistical analysis}

Hierarchical cluster and Multi-Dimensional Scaling (MDS) analyses were carried out with Matlab (The MathWorks, Inc., Natick, MA) as previously described (Palomero-Gallagher et al. 2009) to determine the degree of (dis)similarity of the receptor fingerprints of SPL areas. The number of stabile clusters was determined by a subsequent $k$-means analysis and the elbow method (Rousseeuw 1987). Due to the large differences in the absolute expression levels of the different receptor types examined, receptor densities were normalized by $z$-scores prior to these analyses. In-house MATLAB scripts were also used to compute Mahalanobis distances (Mahalanobis et al. 1949) to determine the (dis) similarity in GLI values between areas of the SPL. Receptors were evaluated for possible differences between SPL areas by means of a MANOVA $(p<0.01)$. Since this was significant, we then carried out, for each receptor type separately, an ANOVA with repeated measures $(p<0.01$; Bonferroni corrected for the 15 receptor types tested) and subsequent paired $t$ tests $(p<0.01)$ to determine which area contributed to the significance. The $p$ values resulting from these posthoc tests were not corrected for multiple testing because 
Table 1 Incubation protocols

\begin{tabular}{|c|c|c|c|c|c|c|c|}
\hline Transmitter & Receptor & Ligand (nM) & Displacer & Incubation buffer & Pre-incubation & $\begin{array}{l}\text { Main incuba- } \\
\text { tion }\end{array}$ & Final rinsing \\
\hline \multirow[t]{3}{*}{ Glutamate } & AMPA & $\begin{array}{l}{\left[{ }^{3} \mathrm{H}\right]-\mathrm{AMPA}} \\
(10.0)\end{array}$ & $\begin{array}{l}\text { Quisqualate } \\
(10 \mu \mathrm{M})\end{array}$ & $\begin{array}{l}50 \mathrm{mM} \text { Tris- } \\
\text { acetate }(\mathrm{pH} \\
7.2)[+100 \mathrm{mM} \\
\mathrm{KSCN}]^{*}\end{array}$ & $\begin{array}{c}3 \times 10 \mathrm{~min} \\
4{ }^{\circ} \mathrm{C}\end{array}$ & $45 \min , 4^{\circ} \mathrm{C}$ & $\begin{array}{l}4 \times 4 \mathrm{~s} \\
\text { Acetone/glu- } \\
\text { taraldehyde } \\
(100 \mathrm{ml}+2.5 \mathrm{ml}) \text {, } \\
2 \times 2 \mathrm{~s}, 4^{\circ} \mathrm{C}\end{array}$ \\
\hline & NMDA & $\begin{array}{l}{\left[{ }^{3} \mathrm{H}\right]-\mathrm{MK}-801} \\
(3.3)\end{array}$ & $\begin{array}{l}(+) \mathrm{MK}-801 \\
(100 \mu \mathrm{M})\end{array}$ & $\begin{array}{l}50 \text { mM Tris- } \\
\text { acetate }(\mathrm{pH} \\
7.2)+50 \mu \mathrm{M} \\
\text { glutmate } \\
{[+30 \mu \mathrm{M}} \\
\text { glycine }+50 \mu \mathrm{M} \\
\text { spermidine }]^{*}\end{array}$ & $15 \min , 4^{\circ} \mathrm{C}$ & $60 \mathrm{~min}, 22^{\circ} \mathrm{C}$ & $\begin{array}{l}2 \times 5 \min , 4^{\circ} \mathrm{C} \\
\text { Distilled water, } \\
1 \times 22^{\circ} \mathrm{C}\end{array}$ \\
\hline & Kainate & $\begin{array}{l}{\left[{ }^{3} \mathrm{H}\right] \text {-Kainate }} \\
(9.4)\end{array}$ & $\begin{array}{l}\text { SYM } 2081 \\
(100 \mu \mathrm{M})\end{array}$ & $\begin{array}{l}50 \mathrm{mM} \text { Tris- } \\
\text { acetate }(\mathrm{pH} \\
7.2)[+10 \mathrm{mM} \\
\left.\mathrm{Ca}^{2+} \text {-acetate }\right]^{*}\end{array}$ & $\begin{array}{l}3 \times 10 \mathrm{~min}, \\
4{ }^{\circ} \mathrm{C}\end{array}$ & $45 \min , 4^{\circ} \mathrm{C}$ & $\begin{array}{l}3 \times 4 \mathrm{~s} \\
\text { Acetone/glutaral- } \\
\text { dehyde } \\
(100 \mathrm{ml}+2.5 \mathrm{ml}) \text {, } \\
2 \times 2 \mathrm{~s}, 22^{\circ} \mathrm{C}\end{array}$ \\
\hline \multirow[t]{3}{*}{ GABA } & $\mathrm{GABA}_{\mathrm{A}}$ & $\begin{array}{l}{\left[{ }^{3} \mathrm{H}\right]-\text { Muscimol }} \\
(7.7)\end{array}$ & $\begin{array}{l}\text { GABA } \\
(10 \mu \mathrm{M})\end{array}$ & $\begin{array}{l}50 \mathrm{mM} \text { Tris-citrate } \\
(\mathrm{pH} 7.0)\end{array}$ & $3 \times 5 \min , 4^{\circ} \mathrm{C}$ & $40 \min , 4^{\circ} \mathrm{C}$ & $\begin{array}{l}3 \times 3 \mathrm{~s}, 4^{\circ} \mathrm{C} \\
\text { Distilled water, } \\
\quad 1 \times 22^{\circ} \mathrm{C}\end{array}$ \\
\hline & $\mathrm{GABA}_{\mathrm{B}}$ & $\begin{array}{l}{\left[{ }^{3} \mathrm{H}\right]-\mathrm{CGP}} \\
54626 \\
(2.0)\end{array}$ & $\begin{array}{l}\text { CGP 55845 } \\
(100 \mu \mathrm{M})\end{array}$ & $\begin{array}{l}50 \mathrm{mM} \text { Tris- } \\
\mathrm{HCl}(\mathrm{pH} \\
7.2)+2.5 \mathrm{mM} \\
\mathrm{CaCl}_{2}\end{array}$ & $3 \times 5 \min , 4^{\circ} \mathrm{C}$ & $60 \mathrm{~min}, 4^{\circ} \mathrm{C}$ & $\begin{array}{l}3 \times 2 \mathrm{~s}, 4^{\circ} \mathrm{C} \\
\text { Distilled water, } \\
1 \times 22^{\circ} \mathrm{C}\end{array}$ \\
\hline & $\begin{array}{l}\text { Benzodiaz- } \\
\text { epine bind- } \\
\text { ing site }\end{array}$ & $\begin{array}{l}{\left[{ }^{3} \mathrm{H}\right] \text {-Fluma- }} \\
\text { zenil } \\
(1.0)\end{array}$ & $\begin{array}{l}\text { Clonazepam } \\
(2 \mu \mathrm{M})\end{array}$ & $\begin{array}{l}170 \mathrm{mM} \text { Tris- } \mathrm{HCl} \\
(\mathrm{pH} 7.4)\end{array}$ & $15 \min , 4^{\circ} \mathrm{C}$ & $60 \mathrm{~min}, 4^{\circ} \mathrm{C}$ & $\begin{array}{l}2 \times 1 \mathrm{~min}, 4^{\circ} \mathrm{C} \\
\text { Distilled water, } \\
1 \times 22^{\circ} \mathrm{C}\end{array}$ \\
\hline \multirow[t]{3}{*}{ Acetylcholine } & $\mathrm{M}_{1}$ & $\begin{array}{l}{\left[{ }^{3} \mathrm{H}\right]-\text { Pirenze- }} \\
\text { pine } \\
(1.0)\end{array}$ & $\begin{array}{l}\text { Pirenzepine } \\
(2 \mu \mathrm{M})\end{array}$ & $\begin{array}{l}\text { Modified Krebs } \\
\text { buffer (pH 7.4) }\end{array}$ & $15 \min , 4^{\circ} \mathrm{C}$ & $60 \min , 4^{\circ} \mathrm{C}$ & $\begin{array}{l}2 \times 1 \mathrm{~min}, 4{ }^{\circ} \mathrm{C} \\
\text { Distilled water, } \\
1 \times 22{ }^{\circ} \mathrm{C}\end{array}$ \\
\hline & $\mathrm{M}_{2}$ & $\begin{array}{l}{\left[{ }^{3} \mathrm{H}\right]-O x o t r e m o-} \\
\text { rine-M (1.7) }\end{array}$ & $\begin{array}{l}\text { Carbacol } \\
(10 \mu \mathrm{M})\end{array}$ & $\begin{array}{l}20 \mathrm{mM} \text { HEPES- } \\
\text { Tris }(\mathrm{pH} \\
7.5)+10 \mathrm{mM} \\
\mathrm{MgCl}_{2}+300 \mathrm{nM} \\
\text { Pirenzepine }\end{array}$ & $20 \min , 22^{\circ} \mathrm{C}$ & $60 \min , 22^{\circ} \mathrm{C}$ & $\begin{array}{l}2 \times 2 \min , 4^{\circ} \mathrm{C} \\
\text { Distilled water, } \\
1 \times 22{ }^{\circ} \mathrm{C}\end{array}$ \\
\hline & $\mathrm{M}_{3}$ & $\begin{array}{l}{\left[{ }^{3} \mathrm{H}\right]-4-\mathrm{DAMP}} \\
(1.0)\end{array}$ & $\begin{array}{l}\text { Atropine sulfate } \\
(10 \mu \mathrm{M})\end{array}$ & $\begin{array}{l}50 \mathrm{mM} \text { Tris- } \\
\mathrm{HCl}(\mathrm{pH} \\
7.4)+0.1 \mathrm{mM} \\
\text { PSMF }+1 \mathrm{mM} \\
\text { EDTA }\end{array}$ & $15 \mathrm{~min}, 22^{\circ} \mathrm{C}$ & $45 \mathrm{~min}, 22^{\circ} \mathrm{C}$ & $\begin{array}{l}2 \times 5 \mathrm{~min}, 4^{\circ} \mathrm{C} \\
\text { Distilled water, } \\
1 \times 22^{\circ} \mathrm{C}\end{array}$ \\
\hline \multirow[t]{2}{*}{ Noradrenaline } & $\alpha_{1}$ & $\begin{array}{l}{\left[{ }^{3} \mathrm{H}\right]-\text { Prazosin }} \\
(0.2)\end{array}$ & $\begin{array}{l}\text { Phentolamine } \\
\text { mesylate } \\
(10 \mu \mathrm{M})\end{array}$ & $\begin{array}{l}50 \mathrm{mM} \mathrm{Na} / \mathrm{K}- \\
\text { phosphate buffer } \\
(\mathrm{pH} 7.4)\end{array}$ & $15 \min , 22^{\circ} \mathrm{C}$ & $60 \min , 22^{\circ} \mathrm{C}$ & $\begin{array}{l}2 \times 5 \min , 4^{\circ} \mathrm{C} \\
\text { Distilled water, } \\
1 \times 22^{\circ} \mathrm{C}\end{array}$ \\
\hline & $\alpha_{2}$ & $\begin{array}{l}{\left[{ }^{3} \mathrm{H}\right]-\mathrm{UK} 14,304} \\
(0,64)\end{array}$ & $\begin{array}{l}\text { Phentolamine } \\
\text { mesylate } \\
(10 \mu \mathrm{M})\end{array}$ & $\begin{array}{l}50 \mathrm{mM} \text { Tris- } \\
\mathrm{HCl}+100 \mu \mathrm{M} \\
\mathrm{MnCl}_{2}(\mathrm{pH} 7.7)\end{array}$ & $15 \min , 22^{\circ} \mathrm{C}$ & $90 \mathrm{~min}, 22^{\circ} \mathrm{C}$ & $\begin{array}{l}5 \mathrm{~min}, 4^{\circ} \mathrm{C} \\
\text { Distilled water, } \\
1 \times 22{ }^{\circ} \mathrm{C}\end{array}$ \\
\hline \multirow[t]{2}{*}{ Serotonin } & $5-\mathrm{HT}_{1 \mathrm{~A}}$ & 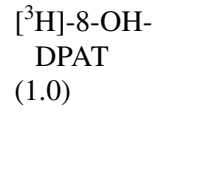 & $\begin{array}{l}\text { 5-Hydroxy- } \\
\text { tryptamine } \\
(1 \mu \mathrm{M})\end{array}$ & $\begin{array}{l}170 \mathrm{mM} \text { Tris- } \\
\mathrm{HCl}(\mathrm{pH} 7.4) \\
{[+4 \mathrm{mM}} \\
\mathrm{CaCl}_{2}+0.01 \% \\
\text { ascorbate }]^{*}\end{array}$ & $30 \mathrm{~min}, 22^{\circ} \mathrm{C}$ & $60 \mathrm{~min}, 22^{\circ} \mathrm{C}$ & $\begin{array}{l}5 \text { min, } 4{ }^{\circ} \mathrm{C} \\
\text { Distilled water, } \\
3 \times 22^{\circ} \mathrm{C}\end{array}$ \\
\hline & $5-\mathrm{HT}_{2}$ & $\begin{array}{l}{\left[{ }^{3} \mathrm{H}\right]-\text { Ketanserin }} \\
(0.5)\end{array}$ & $\begin{array}{l}\text { Mianserin } \\
(10 \mu \mathrm{M})\end{array}$ & $\begin{array}{l}170 \mathrm{mM} \text { Tris- } \mathrm{HCl} \\
\quad(\mathrm{pH} 7.7)\end{array}$ & $30 \min , 22^{\circ} \mathrm{C}$ & $120 \mathrm{~min}, 22^{\circ} \mathrm{C}$ & $\begin{array}{l}2 \times 10 \min , 4^{\circ} \mathrm{C} \\
\text { Distilled water, } \\
3 \times 22^{\circ} \mathrm{C}\end{array}$ \\
\hline
\end{tabular}


Table 1 (continued)

\begin{tabular}{|c|c|c|c|c|c|c|c|}
\hline Transmitter & Receptor & Ligand (nM) & Displacer & Incubation buffer & Pre-incubation & $\begin{array}{l}\text { Main incuba- } \\
\text { tion }\end{array}$ & Final rinsing \\
\hline Dopamine & $\mathrm{D}_{1}$ & $\begin{array}{c}{\left[{ }^{3} \mathrm{H}\right]-\mathrm{SCH}} \\
23390 \\
(1.67)\end{array}$ & $\begin{array}{l}\text { SKF } 83566 \\
(1 \mu \mathrm{M})\end{array}$ & $\begin{array}{l}50 \mathrm{mM} \text { Tris- } \\
\mathrm{HCl}+120 \mathrm{mM} \\
\mathrm{NaCl}+5 \mathrm{mM} \\
\mathrm{KCl}+2 \mathrm{mM} \\
\mathrm{CaCl}_{2}+1 \mathrm{mM} \\
\mathrm{MgCl}_{2}(\mathrm{pH} 7.4)\end{array}$ & $20 \min , 22^{\circ} \mathrm{C}$ & $90 \mathrm{~min}, 22^{\circ} \mathrm{C}$ & $\begin{array}{l}2 \times 20 \min , 4^{\circ} \mathrm{C} \\
\text { Distilled water, } \\
\quad 1 \times 22^{\circ} \mathrm{C}\end{array}$ \\
\hline Adenosine & $\mathrm{A}_{1}$ & $\begin{array}{l}{\left[{ }^{3} \mathrm{H}\right]-\mathrm{DPCPX}} \\
(1.0)\end{array}$ & $\begin{array}{l}\text { R-PIA } \\
(100 \mu \mathrm{M})\end{array}$ & $\begin{array}{l}170 \mathrm{mM} \text { Tris- } \\
\mathrm{HCl}+2 \text { Units/I } \\
\text { Adenosine deam- } \\
\text { inase }[+100 \mu \mathrm{M} \\
\mathrm{Gpp}(\mathrm{NH}) \mathrm{p}]^{*}(\mathrm{pH} \\
7.4)\end{array}$ & $15 \min , 4^{\circ} \mathrm{C}$ & $120 \min , 22^{\circ} \mathrm{C}$ & $\begin{array}{c}2 \times 5 \mathrm{~min}, 4^{\circ} \mathrm{C} \\
\text { Distilled water, } \\
1 \times 22{ }^{\circ} \mathrm{C}\end{array}$ \\
\hline
\end{tabular}

*Only included in the main incubation

they were only performed when the ANOVA tests had been found to be significant.

\section{Results}

Fifteen different receptor types were analysed to provide insights into the molecular organization of SPL areas. These receptors are heterogeneously distributed, both at the regional and at the laminar level, throughout the cortex of the SPL. Some receptors (e.g. AMPA, kainate, $\mathrm{M}_{2}, \mathrm{M}_{3}, \alpha_{1}$ and $5-\mathrm{HT}_{2}$; Fig. 2) were particularly useful to map the SPL, because the inter-areal differences in their expression levels clearly revealed cortical borders, whereas for other receptors (e.g. $D_{1}$ receptor; Fig. 2), inter-areal differences were more subtle. The multimodal approach of the present study not only confirmed the existence of previously described cytoarchitectonic areas, but also enabled the definition of three subdivisions within area PE: areas PEla (or lateral-anterior $\mathrm{PE}$ ) and PEl (lateral PE), and PEm (or medial PE).

\section{Cytoarchitecture of SPL areas}

Figure 3 shows the results obtained from the quantitative cytoarchitectonic analysis of SPL areas. The profiles represent the variations in the volume fraction of cell bodies as GLI (\%) when moving from the pial surface to the border between layer VIb and the white matter. The congruity between the curve representing the mean GLI and those indicating the s.d. values highlights the ideal plane of sectioning of the site selected for GLI measurement. For all areas, a subdivision of layers III $(\mathrm{a}, \mathrm{b}, \mathrm{c}), \mathrm{V}(\mathrm{a}, \mathrm{b})$, and VI (a, b) was detected. As expected, the GLI value is low at the level of layer I, is highest between layers II and V, and then becomes low again in layer VI, particularly in layer
VIb. The proportion of the thickness of each layer and sublayer changes between all the areas. As an example, area V6 shows a thinner layer IV and thicker layers IIIa and $\mathrm{Vb}$ in respect to the adjoining area V6Av.

It is worthwhile to note that differences in the cytoarchitecture (Fig. 4a), as well as in the mean (densities averaged over all layers) and laminar distribution patterns of some of the examined receptors (see below), enabled the subdivision of cytoarchitectonic area PE into three portions: PEm, the dorsal most subdivision, which encroaches onto the mesial surface of the hemisphere, is abutted caudo-laterally by area $\mathrm{PEl}$ and rostro-laterally by area PEla (Fig. 4b). Areas PEm and PEla have a clearly visible columnar organization that is absent in area PEl. About layer thickness, the three areas have a similarly well-developed layer III; on the contrary, layer IV differs between areas: area PEm shows a thick granular layer, which becomes thinner in areas PEla and PEl. Another difference concerns the border with white matter, which is clearly distinct only in area PEla. About the cell population, area PEm shows well-stained cell bodies, with few numbers of large pyramidal cells in layer V. Area PEla, on the contrary, shows a clear strip of large pyramids in layer III, in particular in sublayer IIIc. Area PEl shows a strip of well-impregnated pyramidal neurons in correspondence of layers III. Furthermore, tissue 'grain' is larger, broader, and rougher in PEm, and smaller, finer and more compact in PEl, with PEla showing an intermediate pattern.

The qualitative observations from each of the examined SPL areas were confirmed by computing the Mahalanobis distances between the layer-specific GLI values extracted from each of the examined areas, as shown in Table 2. The highest degree of cytoarchitectural dissimilarities was found for area V6 with respect to PEm, and for area PEci with respect to the nearby area PEc. 
Fig. 2 Coronal sections through three levels of a macaque hemisphere showing exemplary receptor distribution patterns in the SPL. Note the contrast between the relatively homogeneous expression of $D_{1}$ receptors in the cerebral cortex and the heterogeneous distribution patterns of the AMPA, kainate, $\mathrm{M}_{2}, \mathrm{M}_{3}, \alpha_{1}, 5-\mathrm{HT}_{2}$ receptors. White lines on each section represent the borders of SPL areas. Top: silhouette of a macaque brain showing the levels from which the sections presented below were obtained. $D$ dorsal, $M$ mesial, $R$ rostral

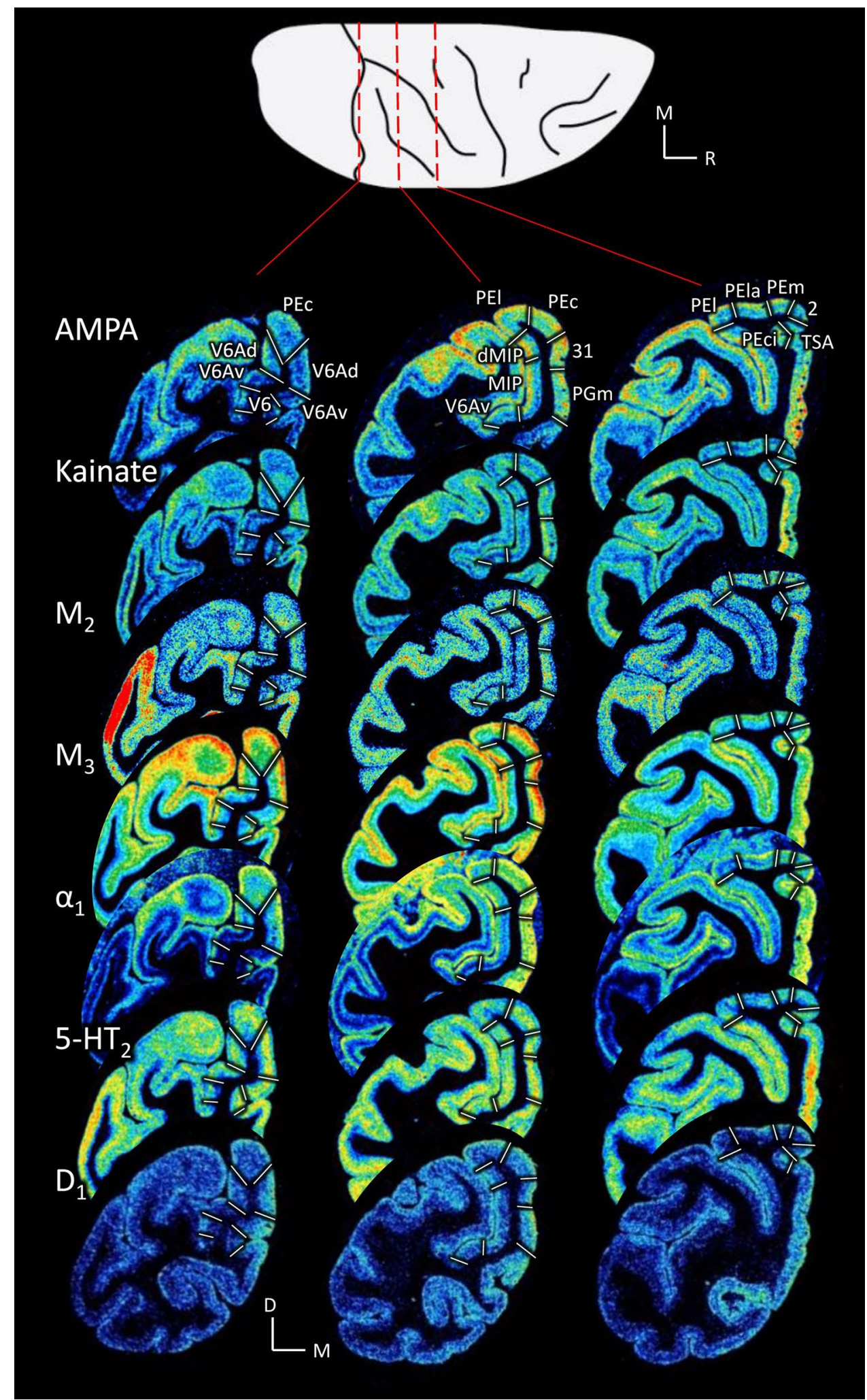

\section{Receptor-architecture of SPL areas}

Figures $5,6,7,8,9,10,11,12$, and 13 show the laminar distribution of the 15 receptors analysed in each cortical area of the SPL. At first sight, it is clear that the highest expression level of most receptor types and subtypes is located in the supragranular layers of all areas, although 

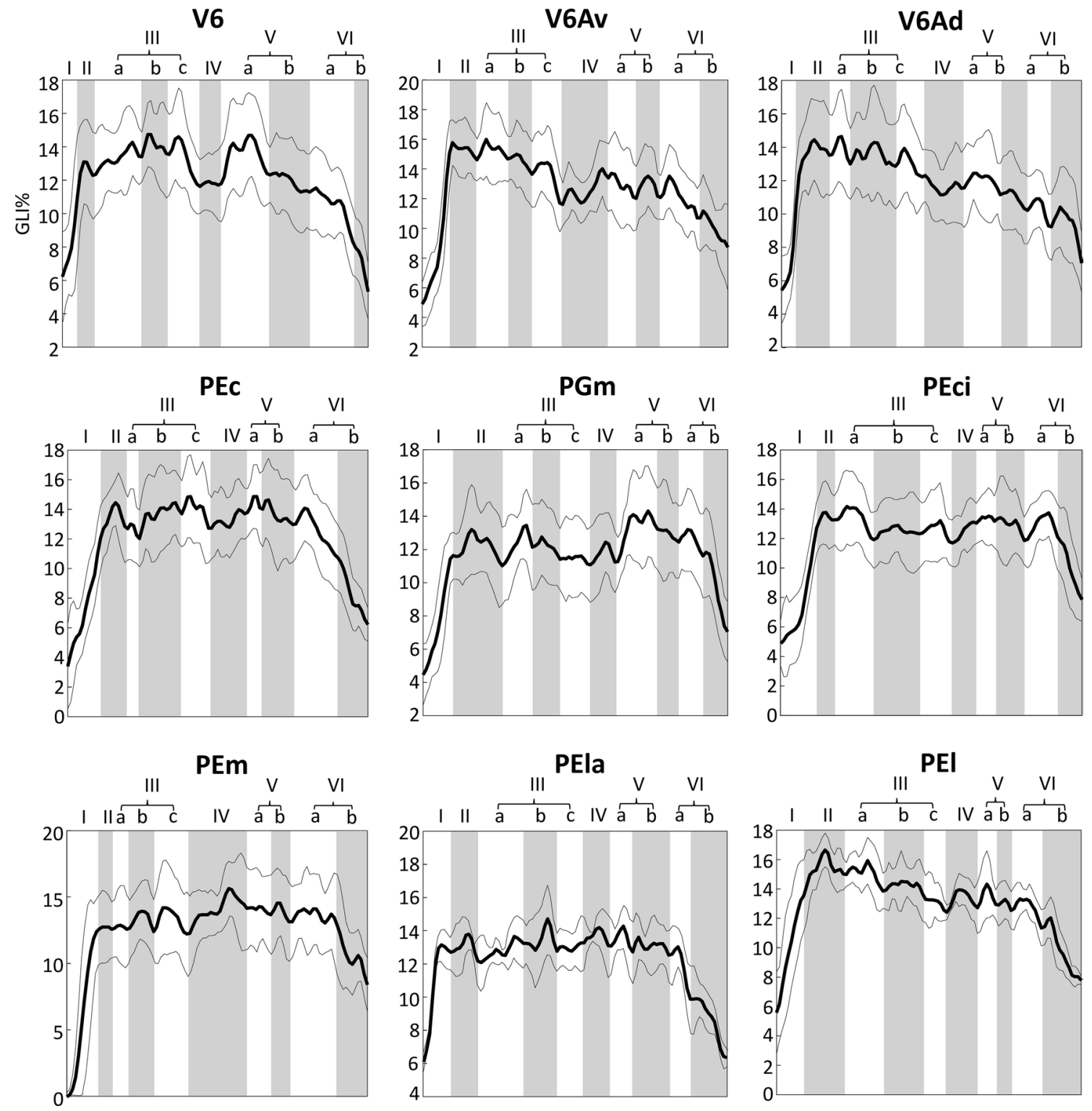

Fig. 3 Grey Level Index (GLI) profiles quantifying the cytoarchitecture of SPL areas. They depict the mean (thick line) \pm s.d. (thin lines) changes in the volume fraction of cell bodies ( $y$ axis) when moving prom the pial surface to the layer VI/white matter border ( $x$ axis)

the absolute values reached by each receptor in a specific layer can vary between areas.

\section{Areas located at the level of parieto-occipital sulcus (pos)}

Three areas are located in the proximity of the parieto-occipital sulcus (pos): areas V6, V6Av, and V6Ad (Fig. 1).

In area V6 (Fig. 5) all receptors reach their maximum expression levels in layers II and/or III. In the glutamatergic family, AMPA and NMDA receptors present the highest densities in layers II and III, whilst receptors for kainate present a local maximum restricted to layer II. GABAergic $\mathrm{GABA}_{\mathrm{A}}$ receptors and $\mathrm{GABA}_{\mathrm{A}} / \mathrm{BZ}$ binding sites show a similar laminar distribution, with highest densities in all the supragranular layers, whereas $\mathrm{GABA}_{\mathrm{B}}$ receptors are more selective for layer II. Muscarinic $\mathrm{M}_{1}, \mathrm{M}_{2}$, and $\mathrm{M}_{3}$ receptors present comparable distribution patterns, since they all reach their maximum expression levels in layers II and III, although the $\mathrm{M}_{2}$ density is lower than that of $\mathrm{M}_{1}$ and $\mathrm{M}_{3}$ receptors. The $\alpha$-adrenergic receptor of type 1 presents a more restricted distribution compared to the $\alpha_{2}$ receptor, since the former is confined to layers II and IIIa, while the latter is present at considerably higher densities in all supragranular layers than in the infragranular ones. The serotoninergic receptors present a differential distribution pattern, where high 5- $\mathrm{HT}_{1 \mathrm{~A}}$ receptor densities are confined 

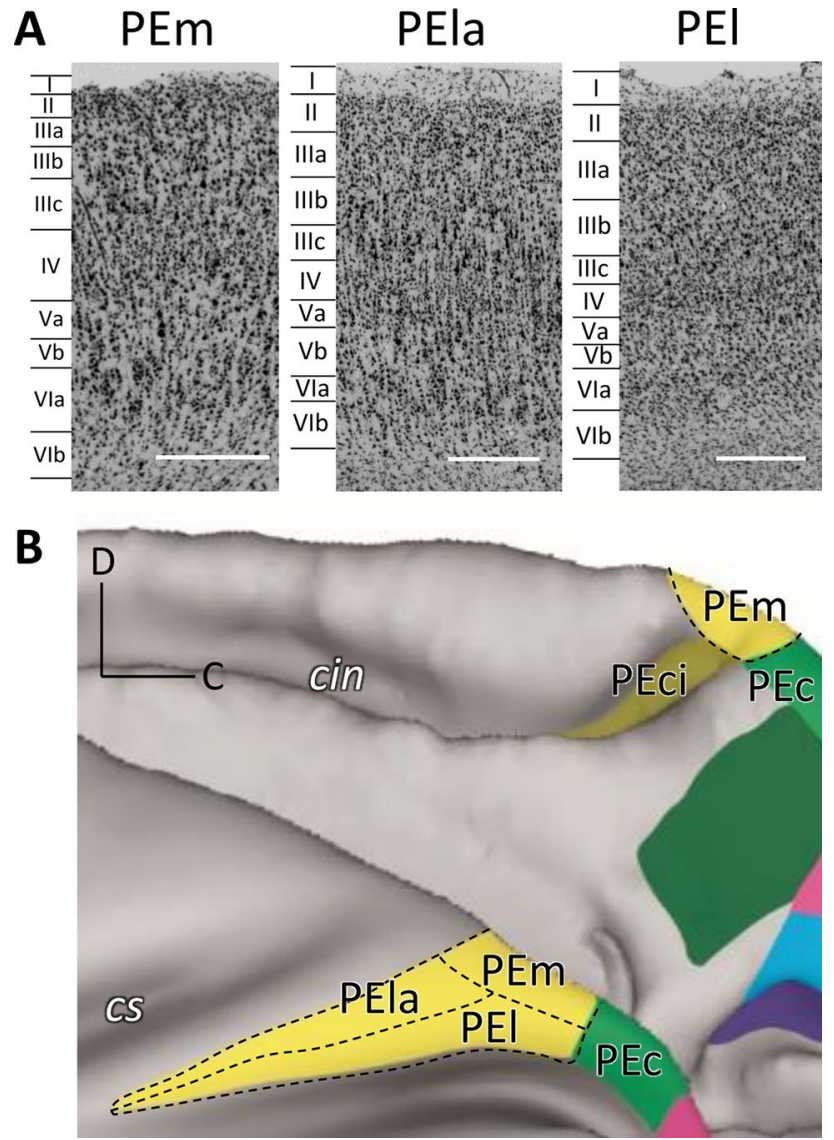

Fig. 4 a Cytoarchitectonic pattern of areas PEm, PEla, and PEl. High magnification views of Nissl-stained segments of the three parts of area PE are shown. Scale bars $=500 \mu \mathrm{m}$. b Schematic visualization of the spatial relationship between the subdivisions of area PE. Other details and abbreviations as in Fig. 1

to layers I-II, while highest $5-\mathrm{HT}_{2}$ receptor densities are reached layers I-Va, with the highest density in layer III (in particular sublayer IIIc). The $\mathrm{D}_{1}$ receptor is present at a very low density throughout the cortex, but there is a higher density in the supra- than in the infragranular layers. The purinergic receptor for adenosine of type $1\left(A_{1}\right)$ shows a different distribution with respect to all the other receptors analysed, since high concentrations were present in layers III-VI, with the highest concentrations in layers IIIc and IV.

Area V6Av (Fig. 6) shows a laminar receptor density pattern similar to area V6, although several important differences are evident. At first, the absolute density of most receptors is higher than in area V6 (Fig. 14), and reached the level of significance for the AMPA, kainate, $\alpha_{1}$, and 5-HT receptors. Furthermore, highest $\mathrm{A}_{1}$ receptor densities are mainly located in the infragranular layers, and the $\alpha_{2}$ receptor presents a more homogeneous distribution throughout all cortical layers.

Area V6Ad is located dorsally to V6Av and close to the exposed surface of the SPL (Fig. 1). In area V6Ad (Fig. 7) the absolute receptor density continues to increase compared to V6Av and V6 (Fig. 14). The densities of AMPA, $\alpha_{1}$, and $5-\mathrm{HT}_{1 \mathrm{~A}}$ receptors, as well as of $\mathrm{GABA}_{\mathrm{A}} / \mathrm{BZ}$ binding sites are significantly higher in V6Ad than in V6Av. Differences also exist at the laminar level, the most prominent of which are that in V6Ad the 5- $\mathrm{HT}_{1 \mathrm{~A}}$ receptor density is very high at layers II-IIIa, and the highest kainate and $\mathrm{A}_{1}$ densities are mainly located in the infragranular layers. Furthermore, $\mathbf{M}_{2}$ receptor density is very low and homogeneously distributed throughout all layers of V6Ad, whereas the $\alpha_{2}$ receptor presents a conspicuous maximum in layer I.

\section{Areas located on the exposed surface of the SPL}

The exposed surface of the superior parietal lobule is composed by two cytoarchitectonic areas, namely PEc and PE (Fig. 1). These two areas differ considerably in their laminar receptor distribution patterns. Furthermore, the receptorarchitecture of PEc more closely resembles that of area PGm than it does that of PE. Indeed, PEc and PGm do not differ significantly from each other in the mean (averaged over all layers) densities of any of the examined receptor types, whereas PEc contains significantly higher kainate and $\alpha_{1}$ receptor densities than do the subdivisions of PE.
Table 2 Matrix of Mahalanobis distances between areas of the SPL

\begin{tabular}{llllllllll}
\hline & PEc & PEl & PEla & PEm & PEci & PGm & V6Ad & V6Av & V6 \\
\hline PEc & 0 & & & & & & & & \\
PEl & 5.21 & 0 & & & & & & \\
PEla & 4.24 & 4.48 & 0 & & & & & \\
PEm & 7.39 & 5.15 & 7.97 & 0 & & & & \\
PEci & 9.57 & 6.43 & 8.92 & 7.04 & 0 & & & \\
PGm & 7.06 & 6.55 & 5.41 & 7.78 & 4.77 & 0 & & \\
V6Ad & 5.00 & 2.55 & 5.17 & 6.85 & 8.38 & 8.08 & 0 & \\
V6Av & 7.92 & 3.23 & 5.49 & 8.46 & 5.64 & 6.23 & 2.69 & 0 & \\
V6 & 4.63 & 4.19 & 5.96 & 9.30 & 8.28 & 5.80 & 4.41 & 6.75 & 0 \\
\hline
\end{tabular}

Analysis was based on the mean GLI\% of each area 
Fig. 5 Cyto- and receptor-architecture of area V6. To the left, a Nissl-stained segment is shown. The same segment taken from the corresponding neighbouring autoradiographs is shown for all the 15 receptors analysed. Colour scale codes for receptor densities. Scale bar $=500 \mu \mathrm{m}$
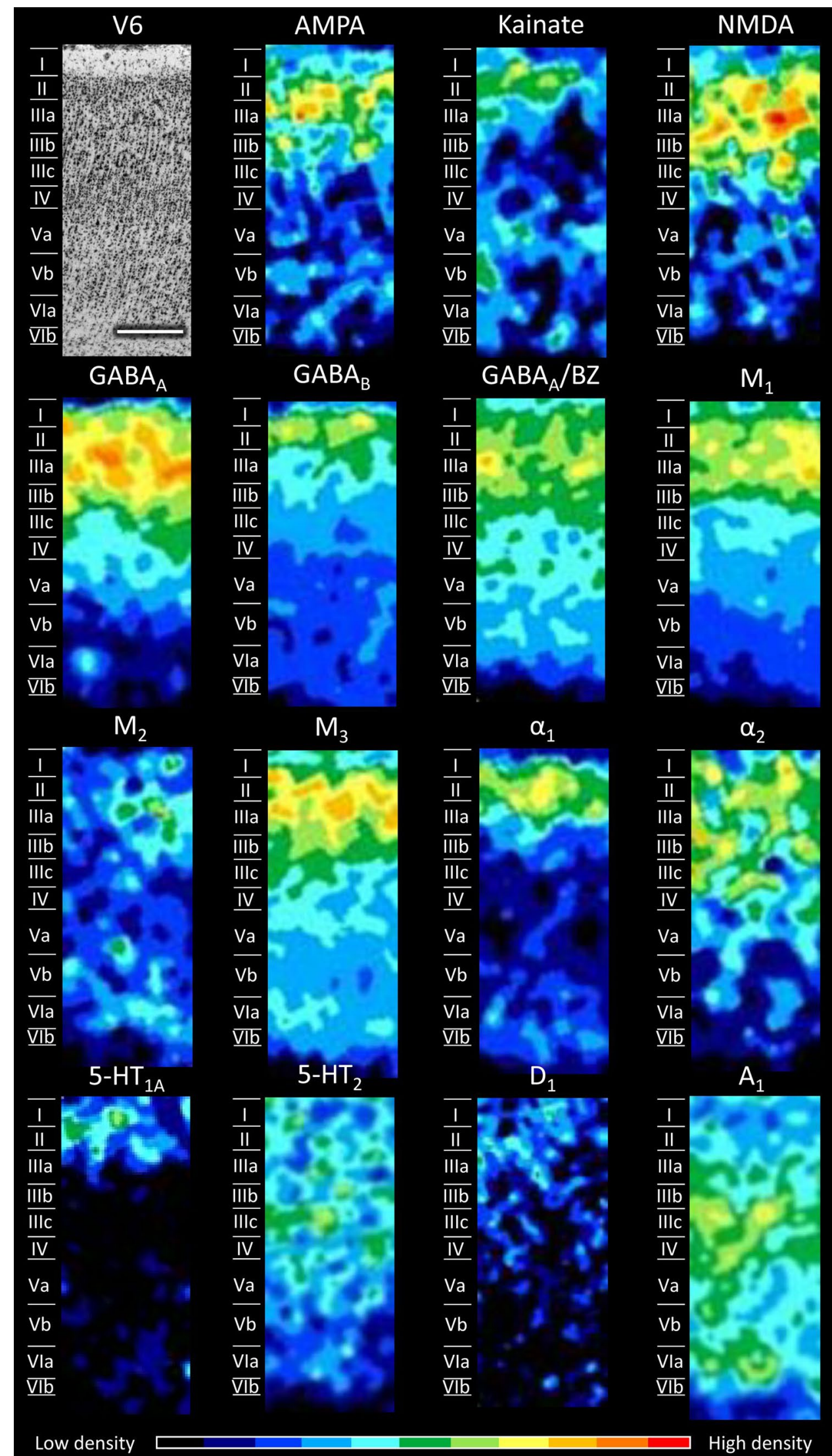
Fig. 6 Cyto- and receptor-architecture of area V6Av. Other details in Fig. 5
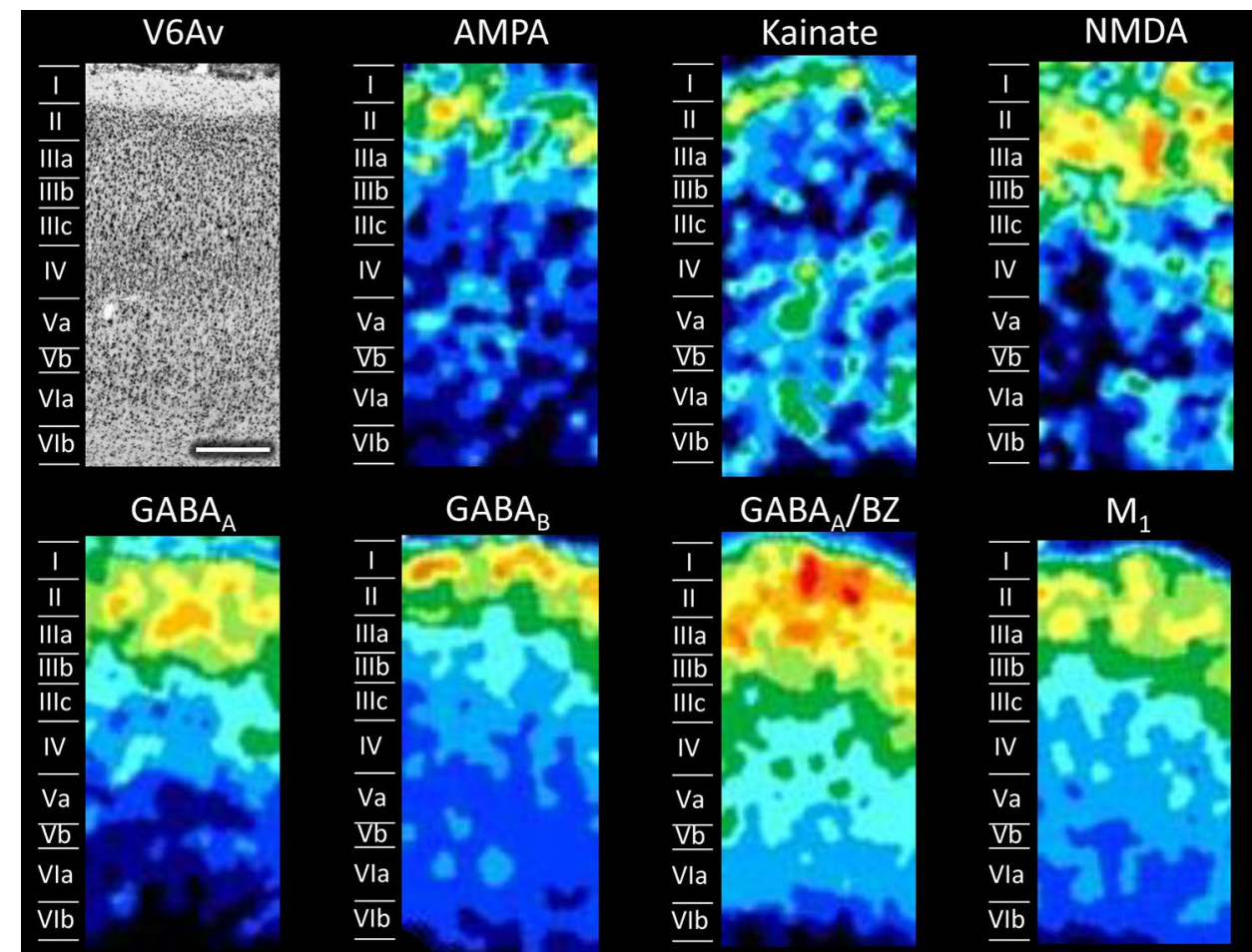

$\mathrm{M}_{2}$

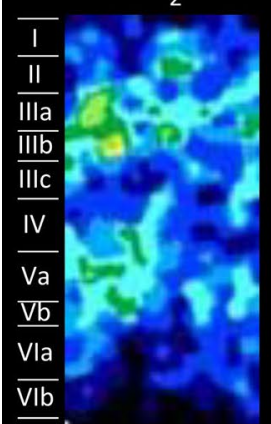

$\mathrm{M}_{3}$

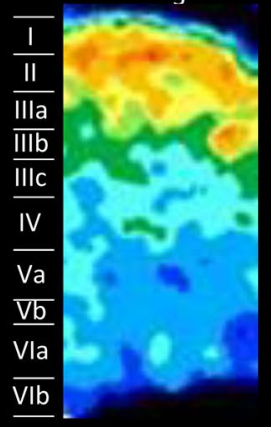

$\alpha_{1}$
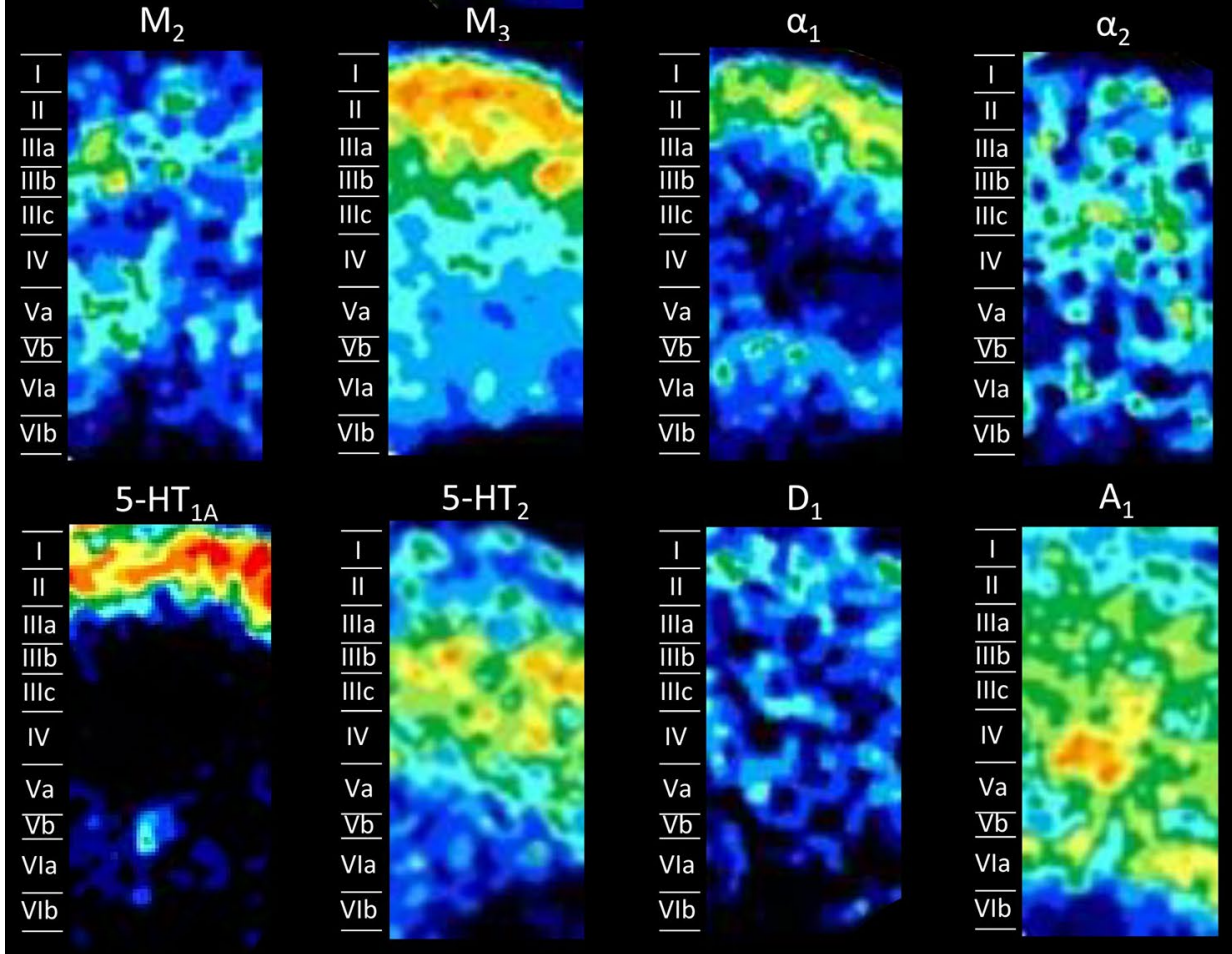

Low density
Area PEc contains significantly higher AMPA, $\alpha_{1}$, and $5-\mathrm{HT}_{1 \mathrm{~A}}$ receptor densities than does V6Ad. The laminar distribution patterns in area PEc (Fig. 8) also differs clearly from those of areas located at the level of the pos, mainly due to higher densities, particularly of AMPA, kainate, and $\mathrm{M}_{2}$ receptors, in the infragranular layers of PEc than in those of V6Ad (Fig. 14). The $\mathrm{M}_{2}$ receptor presents a local maximum in layer $\mathrm{V}$, and kainate receptors present higher densities in the infra- than in the supragranular layers of PEc. Different from all the other SPL 
Fig. 7 Cyto- and receptor-architecture of area V6Ad. Other details in Fig. 5
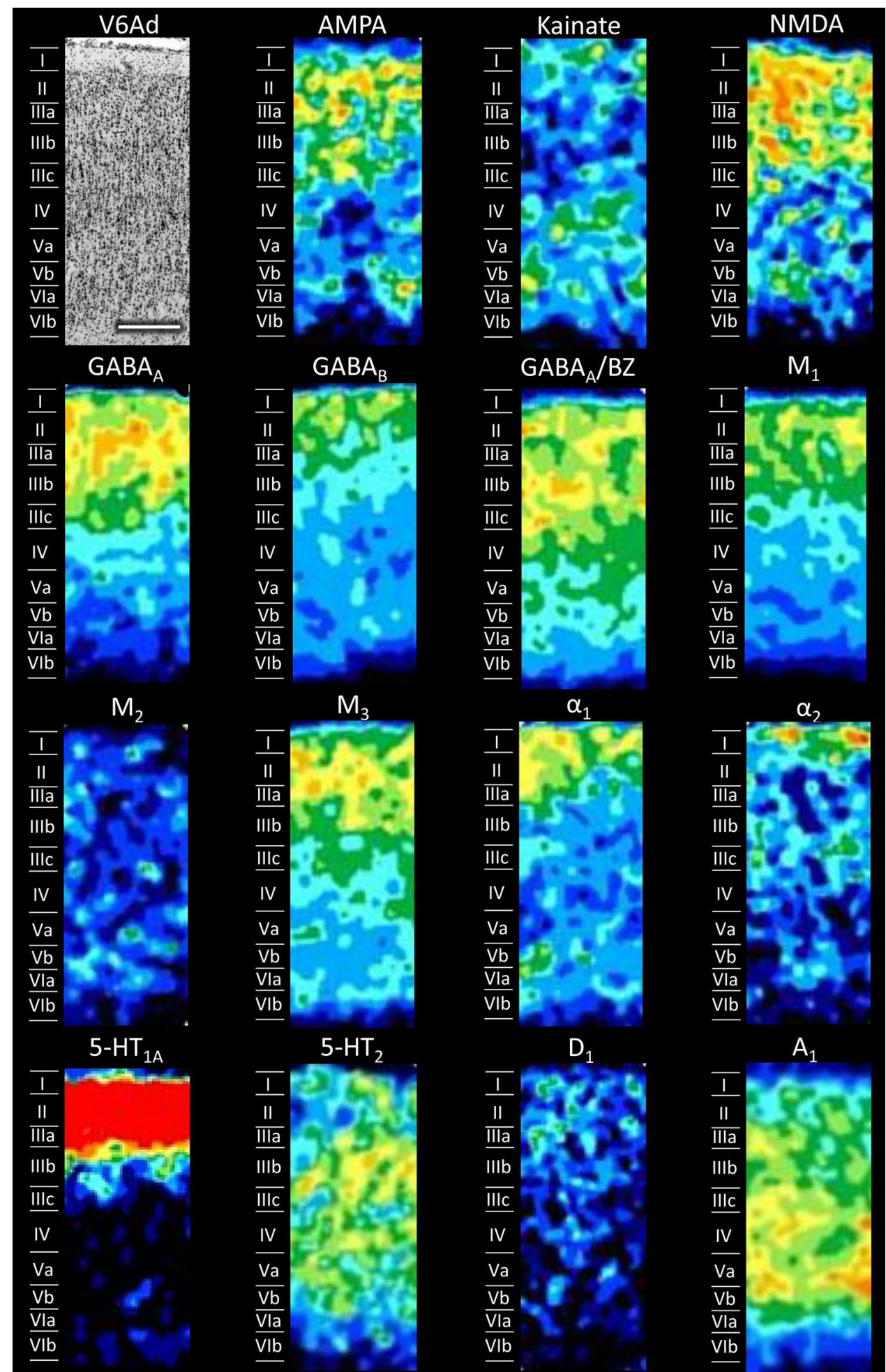

$\mathrm{D}_{1}$
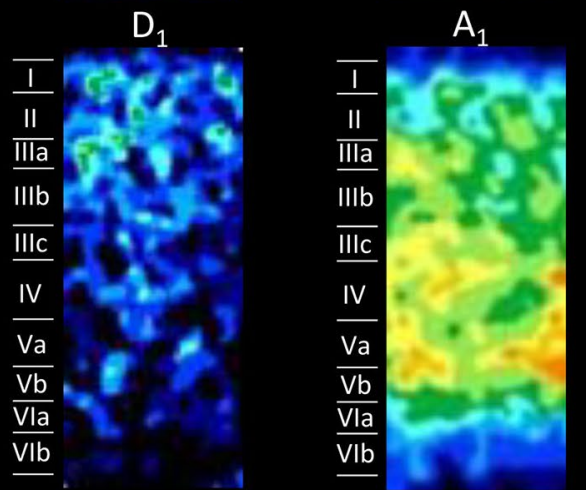

Low density

High density areas, AMPA receptors are homogeneously distributed throughout PEc.

Differences in the laminar distribution patterns and in the mean receptor densities (averaged over all cortical layers; see below) of some of the examined receptors confirmed the subdivision of area PE into areas PEm, PEla and PEl. These three subdivisions of area PE (Figs. 9, 10, 11) present, of course, similarities between them, but important 
Fig. 8 Cyto- and receptorarchitecture of area PEc. Other details in Fig. 5
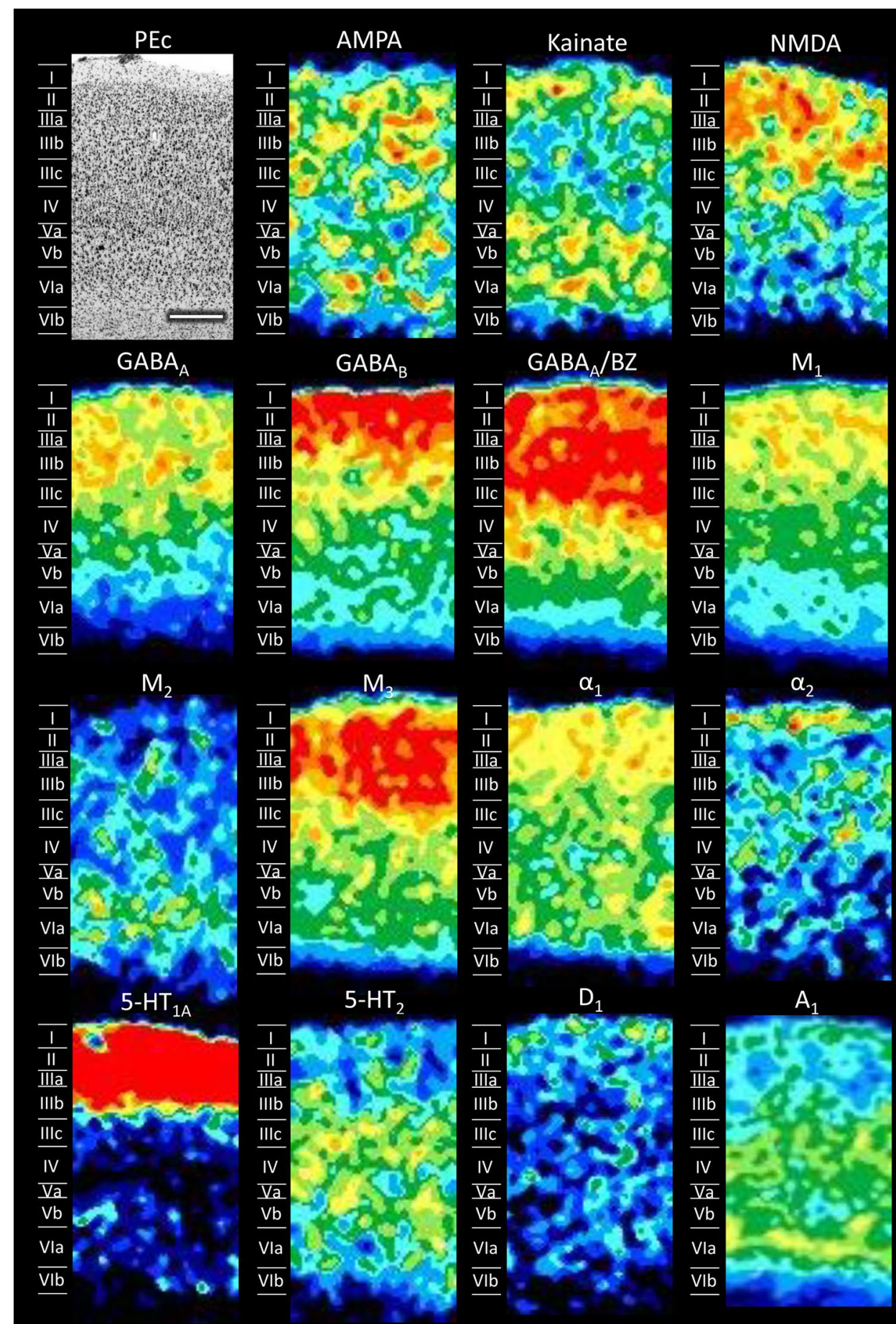

$\mathrm{D}_{1}$

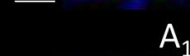

Low density

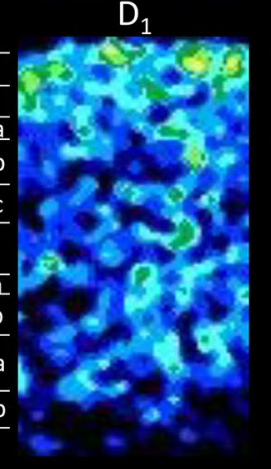

c.
$A_{1}$

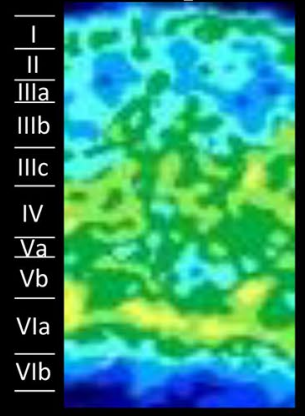

High density differences are also evident. At the mean receptor level, PEla contains significantly lower AMPA and 5- $\mathrm{HT}_{1 \mathrm{~A}}$ densities than PEm and PEl, respectively. Most receptors are present in higher concentrations in the supragranular than in the infragranular layers of all three subdivisions of $\mathrm{PE}$, though exceptions are given by kainate, $\mathrm{M}_{2}, \alpha_{1}$, and $\mathrm{A}_{1}$ receptors. AMPA receptors show a bilaminar distribution pattern in all three subdivisions of PE; however, while in PEm and PEla the densities in the supragranular layers are clearly higher than those in the infragranular layers, in PEl the supragranular layers present only slightly higher densities than the infragranular ones. The NMDA receptor reveals the border between the medial and lateral subdivisions of PE: whereas PEla and PEl present higher densities in the supragranular 
Fig. 9 Cyto- and receptorarchitecture of area PEm. Other details in Fig. 5

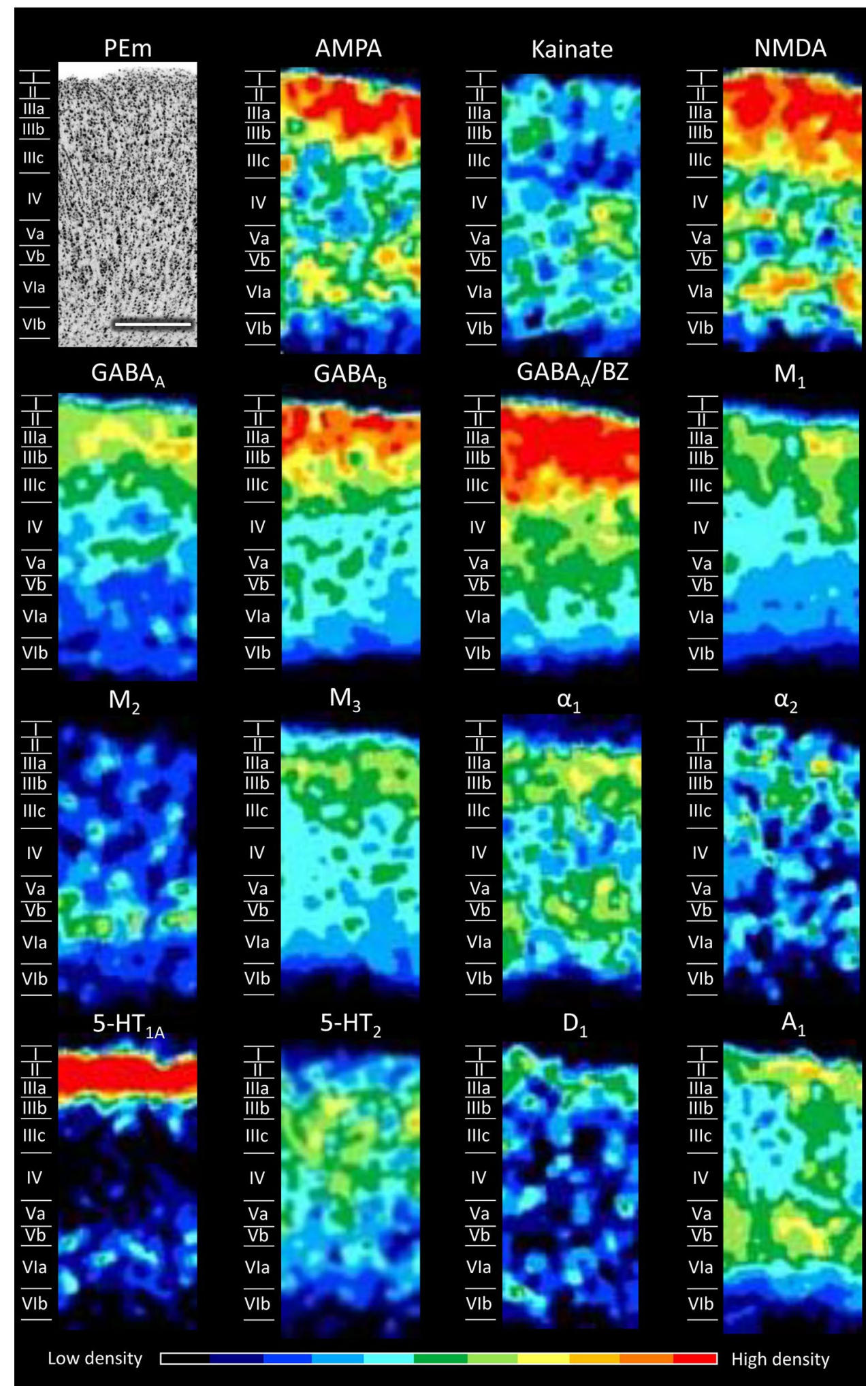

than in the infragranular layers, PEm shows a second local maximum in layer VI (Fig. 9). The $\alpha_{1}$ receptor enables the delineation of PEla from PEl and PEm, since it does not contain the local minimum over layers IIIc-IV that is clearly visible in the two latter areas. Finally, the $\mathrm{A}_{1}$ receptor has a different laminar pattern in each of the subdivisions: in area 
Fig. 10 Cyto- and receptorarchitecture of area PEla. Other details in Fig. 5

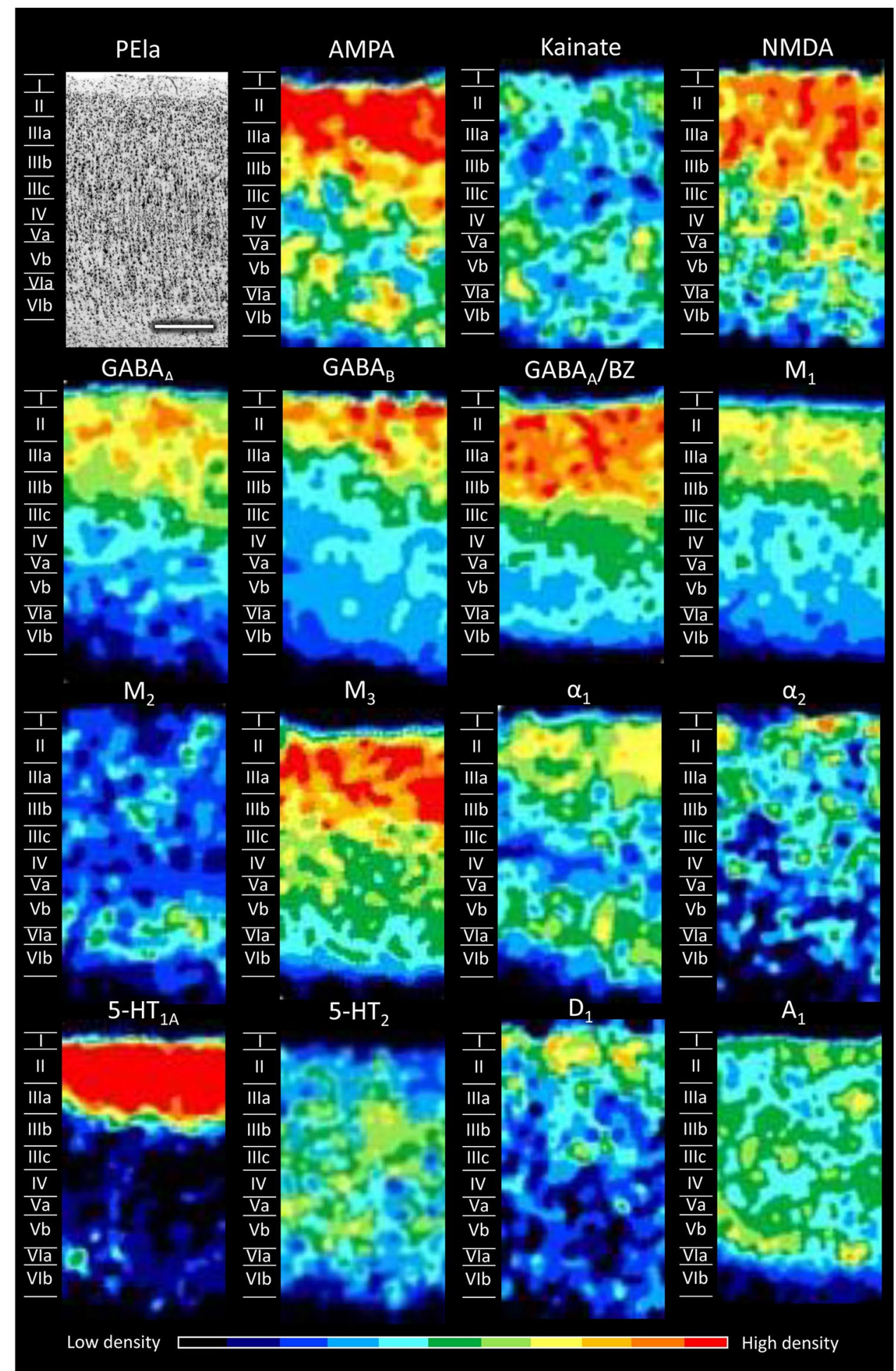

PEl highest densities extend between layers IIIb and VI, area PEla shows a relatively homogeneous distribution, and in area PEm two local maxima are visible, one involving layers I and II, the other layers V and VIa.

\section{Areas located on the mesial surface}

On the mesial surface of the hemisphere, two areas were found: area PGm, located in the precuneate cortex, and area PEci, located within the caudal tip of the cingulate sulcus (Fig. 1). 
Fig. 11 Cyto- and receptorarchitecture of area PEl. Other details in Fig. 5

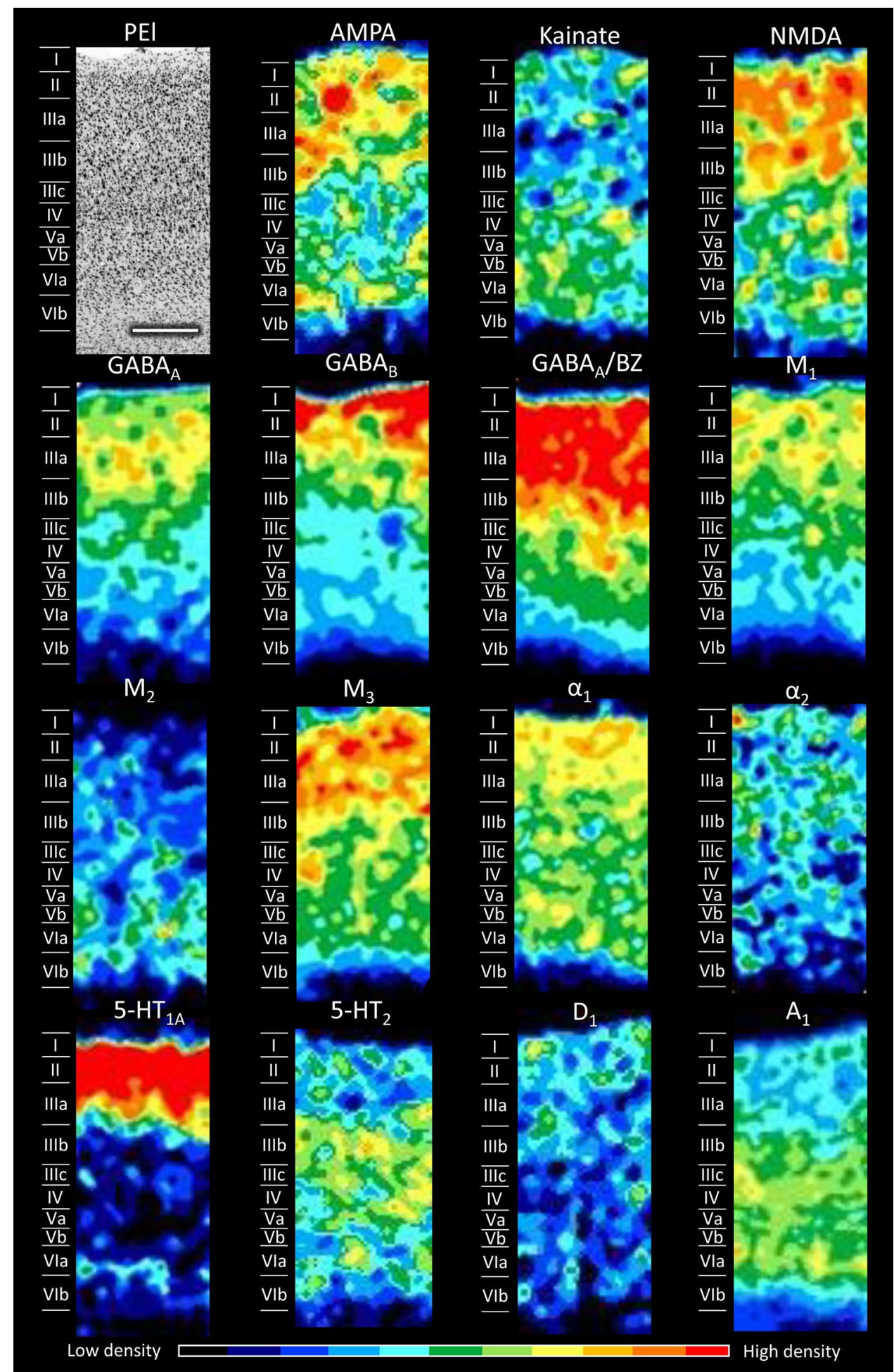

Area PEci (Fig. 12) more closely resembles the subdivisions of area PE, and in particular PEla, than does PGm. PEci and PEm differ significantly in their AMPA and 5-HT ${ }_{1 \mathrm{~A}}$ receptor densities, which are higher in the former area. PEci also contains significantly higher $5-\mathrm{HT}_{1 \mathrm{~A}}$ receptor densities than do PEla or PEl. The main difference between areas PEci and PEla is in their absolute receptor densities (particularly concerning the NMDA, $\mathrm{M}_{3}$ and 5- $\mathrm{HT}_{1 \mathrm{~A}}$ receptors; Fig. 14), although there are also differences in the laminar distribution pattern of the $A_{1}$ receptor, which in area PEci is present in high concentrations only in the infragranular layers, whilst it is homogeneously distributed throughout area PEla. 
Fig. 12 Cyto- and receptorarchitecture of area PEci. Other details in Fig. 5

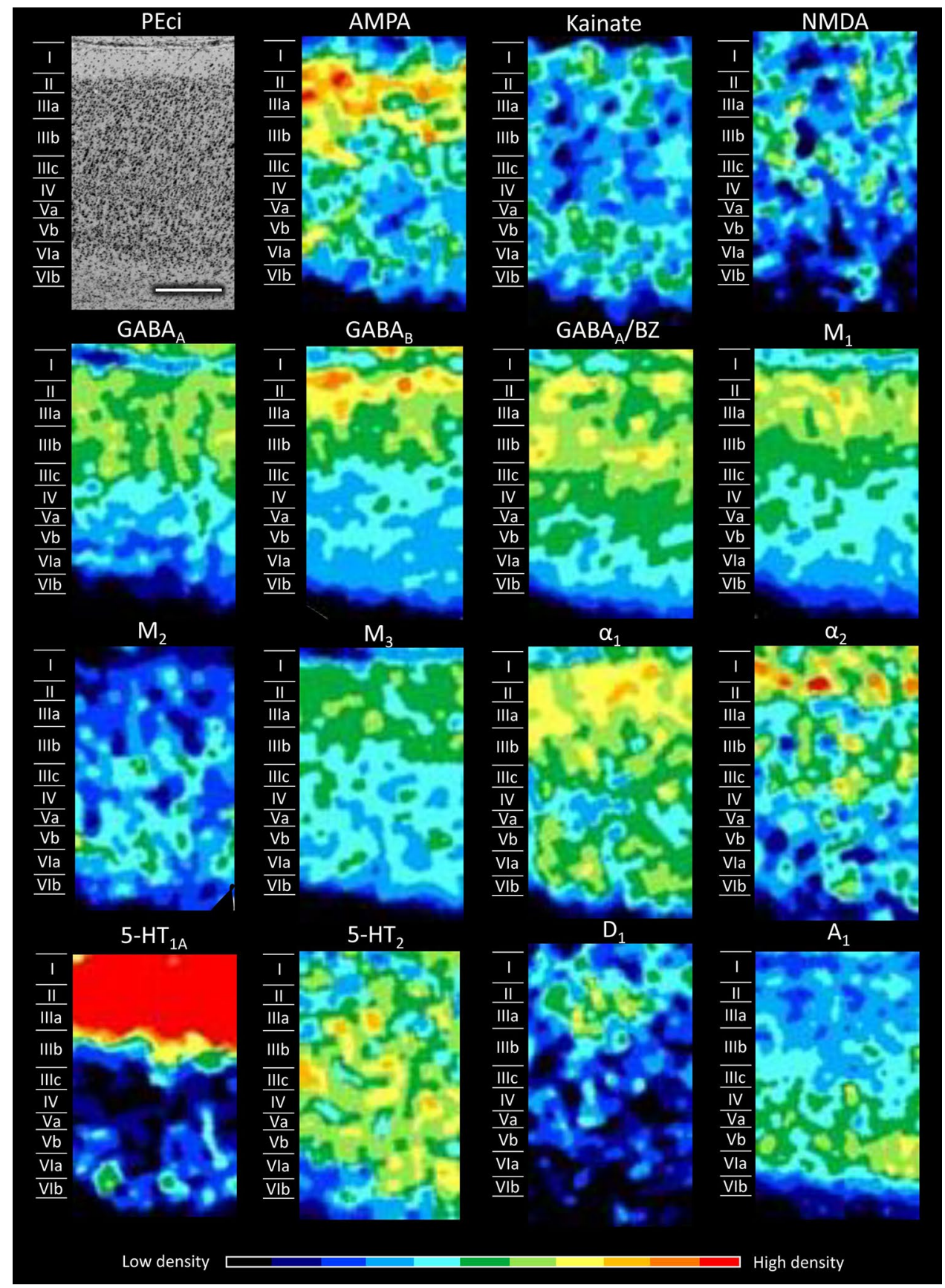

As mentioned above, PGm (Fig. 13) is more similar to PEc than to the subdivisions of PE. Mean receptor densities of PGm do not differ significantly from those measured in PEc. Furthermore, densities of NMDA, GABA ${ }_{A}, \alpha_{1}$, and $5-\mathrm{HT}_{2}$ receptors are comparable in PEm, PEla and PEl, but conspicuously lower than those of PEc or PGm. Additionally, PGm shows a laminar receptor pattern which is very similar to that of PEc. All the receptors are mainly expressed in supragranular layers, with the exception of kainate, $\mathbf{M}_{2}$, 5- $\mathrm{HT}_{2}$ and $\mathrm{A}_{1}$ receptors, showing a reverted pattern. Major differences between PGm and PEc are visible only for the laminar distribution patterns of AMPA, $\alpha_{2}$ and $D_{1}$ receptors. The density of AMPA receptors is widespread in PEc but mainly concentrated in the supragranular layers in PGm. Another difference regards $\alpha_{2}$ receptor, confined in layer III in PGm, whilst in PEc (Fig. 8) it is organized in two bands, one denser at the level of layer I and another one in correspondence of layer III, with a low-density zone in layer II. An additional difference is visible comparing $\mathrm{D}_{1}$ receptor, which presents a low density even if shifted towards layer I in PEc, but reaching high amounts in PGm, and more with the involvement of layers II and IIIa. 
Fig. 13 Cyto- and receptorarchitecture of area PGm. Other details in Fig. 5

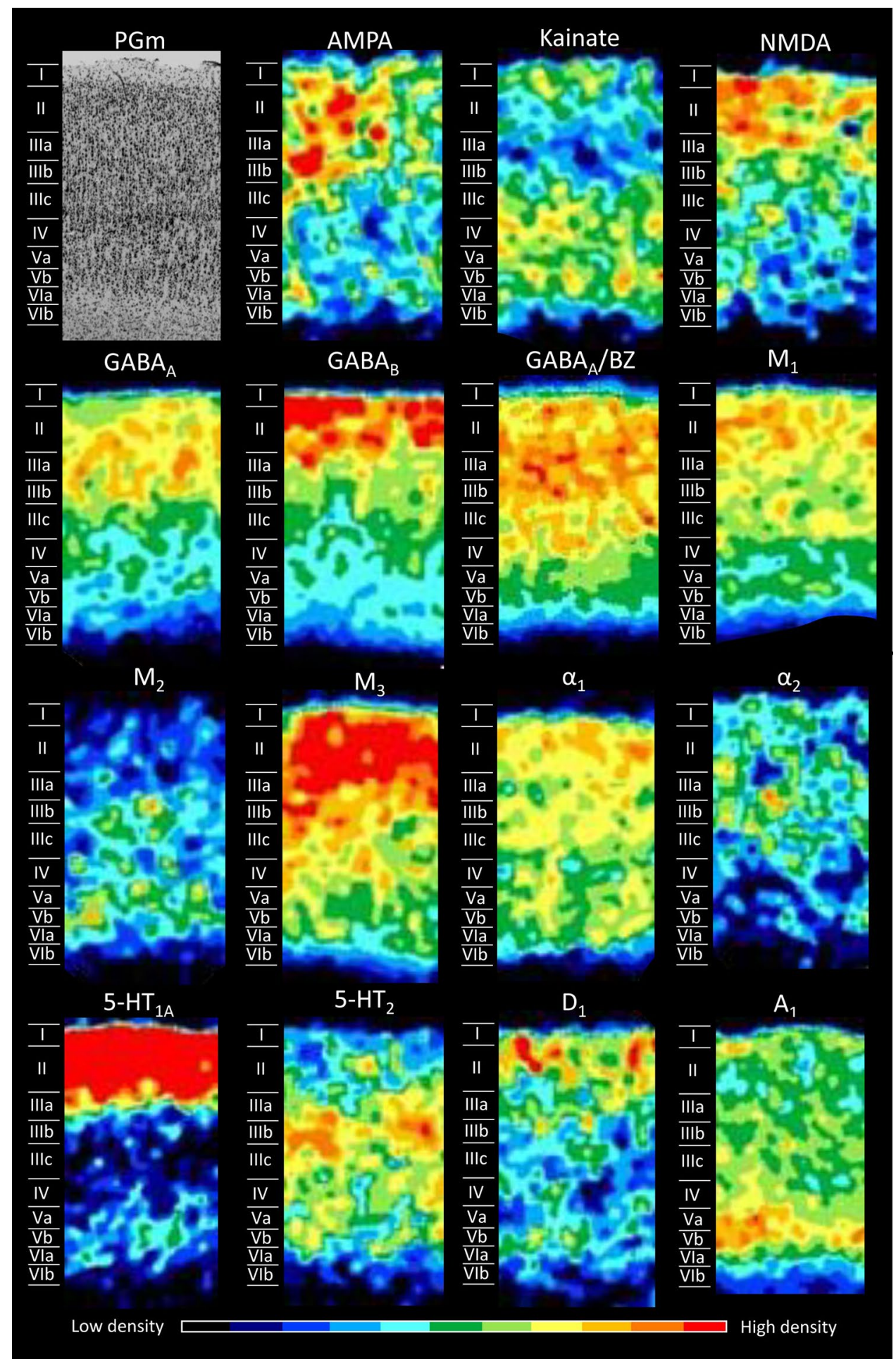

\section{Receptor fingerprints}

Figure 14 summarizes the data of the mean density (averaged over all cortical layers) for all the receptors analysed for each area. All areas share the common characteristic that GABAergic and NMDA receptors are the most highly expressed types in all areas. Furthermore, $\mathrm{M}_{1}, \mathrm{M}_{3}$ and $\mathrm{A}_{1}$ receptors are present at higher densities than the remaining receptor types, and the $D_{1}$ receptor is present at the lowest concentration. Area V6 has the smallest receptor fingerprint, thus highlighting the fact that it contains the lowest mean densities of receptors measured within areas of the SPL, and areas PEc and PGm have the largest receptor fingerprints. Figure 14 shows how the increase in absolute densities 


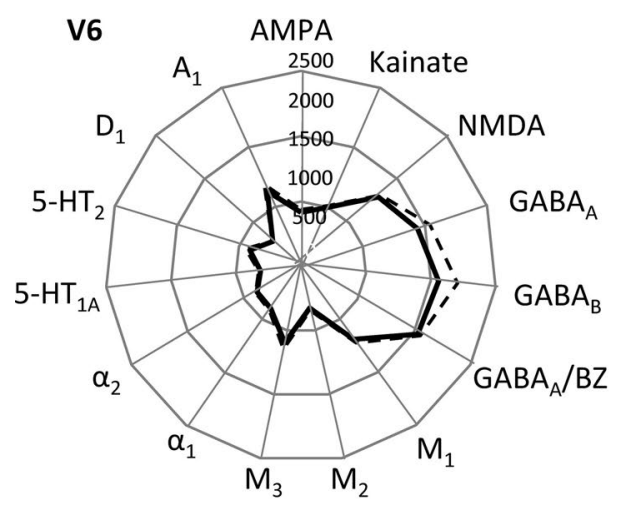

V6Av

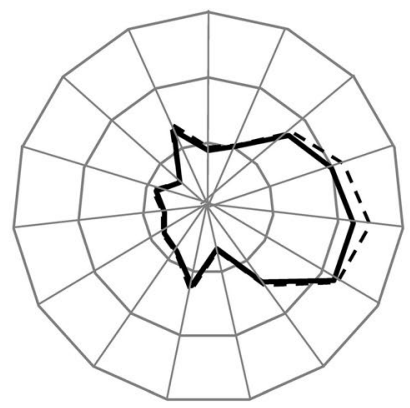

PEc

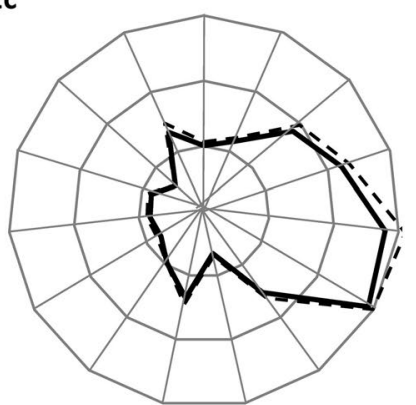

PEI

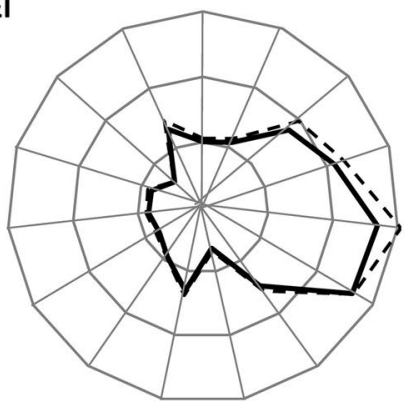

PEm

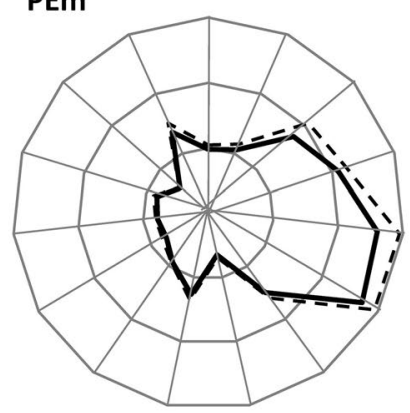

PEci

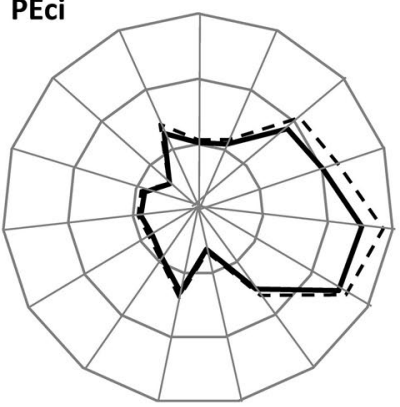

V6Ad

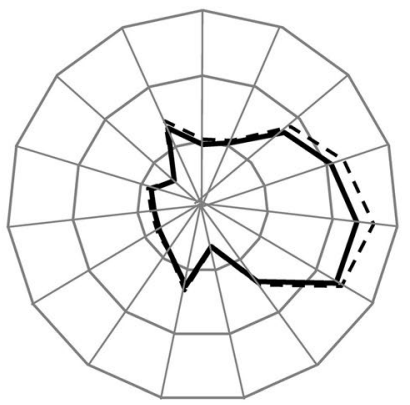

PEla

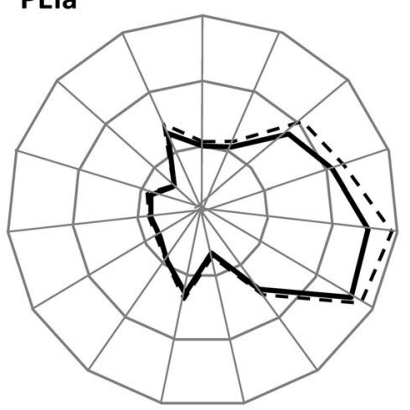

PGm

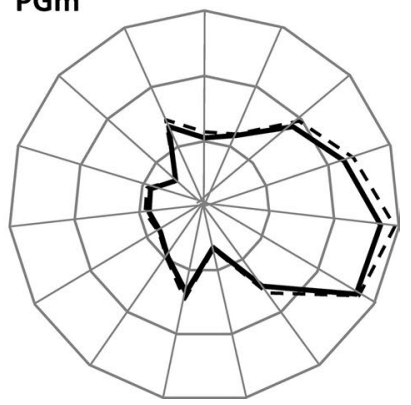

Fig. 14 Receptor fingerprints of SPL areas. Continuous lines connect the mean densities and dashed lines the s.d. values. The data are expressed in $\mathrm{fmol} / \mathrm{mg}$ protein

observed when moving from V6 through V6Av to V6Ad and PEc is reflected in an increase in the size of their respective fingerprints.

The MANOVA revealed that, under simultaneous consideration of all receptor types, SPL areas differ significantly from each other, and the subsequent ANOVAs identified the changes in the densities of AMPA, kainate, $\alpha_{1}$ and 5-HT $1 \mathrm{~A}$ receptors, as well as of $\mathrm{GABA}_{\mathrm{A}} / \mathrm{BZ}$ binding sites as the main differences driving this significance.

The analysis of mean receptor densities also allowed us to identify medial and lateral subdivisions within areas V6Av and V6Ad. Indeed, receptor densities are higher in the medial than in the lateral parts of the two areas (Figs. 2 and 15). In the case of areas V6Avl and V6Avm, this difference reached significance for the kainate receptors, whereas V6Adl and V6Adm differed significantly in their 5-HT $1 \mathrm{~A}$ densities. However, we observed that these differences in mean densities were not accompanied by differences in cytoarchitecture or in the laminar distribution patterns of the examined receptors.

\section{Multivariate analyses}

Multivariate analyses were carried out to assess the degree of (dis)similarity of the receptor fingerprints of areas of the SPL. The $k$-means analysis revealed that areas of the SPL could be divided into four clusters based on their receptor fingerprints. The hierarchical cluster analysis revealed a first clear separation of areas V6, V6Avl, V6Avm and V6Adl (branch 1; Fig. 16a) from area V6Adm and the areas on the lateral and medial aspects of the SPL (branch 2; Fig. 16a). Furthermore, area V6 builds a cluster on its own (branch 

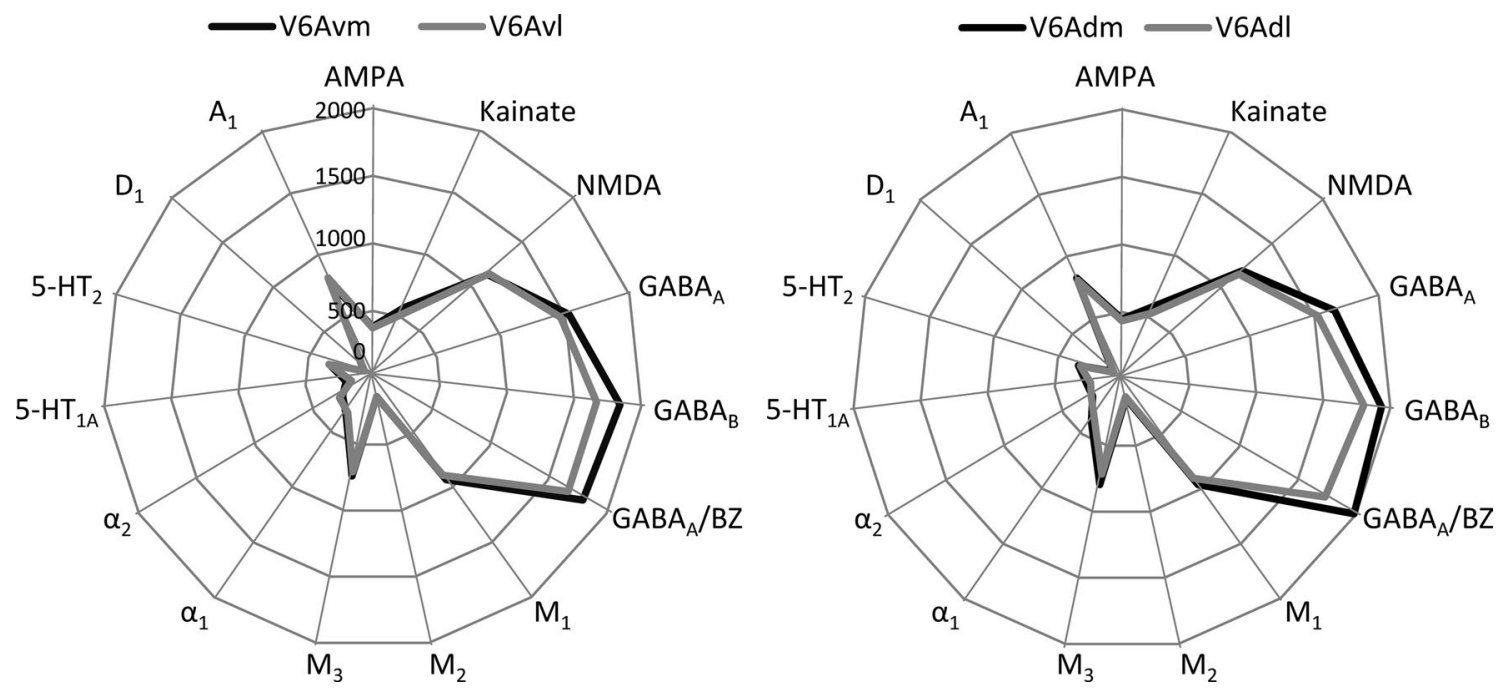

Fig. 15 Receptor fingerprints of the medial and lateral subdivisions of areas V6Av and V6Ad. Continuous lines connect the mean densities and dashed lines the s.d. values. The data are expressed in $\mathrm{fmol} / \mathrm{mg}$ protein

1a; Fig. 16a), whereas areas V6Avl, V6Avm and V6Adl are located within one cluster (branch 1b; Fig. 16a). This clear segregation of area V6 from V6Ad and V6Av is also confirmed by the multidimensional scaling analysis (Fig. 16b). Interestingly, V6Adm is found in the same cluster as areas PEm, PEl and PEla (branch 2a; Fig. 16a). In the multidimensional scaling analysis, V6Adm takes an intermediate position between the subdivisions of area PE and areas V6Avl, V6Avm and V6Adl (Fig. 16b). Finally, areas PEc, PEci and PGm are found in a common cluster of the dendrogram (branch 2b; Fig. 16a), but are clearly segregated by the second dimension of the multidimensional scaling analysis (Fig. 16b).

\section{Discussion}

The present study constitutes a multimodal analysis of areas located in the SPL, encompassing both their cytoarchitecture and multi-receptor expression patterns. This approach not only enabled the definition of hitherto undescribed borders within the SPL, namely the subdivisions of area PE, but also provided new insights into the functional organization of SPL areas. Based on the present findings, and in view of recent advances in our understanding of the structural and functional organization of the primate superior parietal lobule, we here propose a novel pattern of homologies between areas of the human and macaque SPL (see below).

The first insight resulting from the receptor density analysis is that receptors for GABA and glutamate are the predominant receptor types in all the areas of the SPL. This finding is in line with observations in other macaque brain regions such as the primary sensory (Zilles and Palomero-Gallagher
2017) and cingulate (Bozkurt et al. 2005; Palomero-Gallagher et al. 2013) cortices, as well as with analyses of homologue regions in the human brain (Eickhoff et al. 2007; Palomero-Gallagher et al. 2009, 2013; Scheperjans et al. 2005a, b; Zilles and Palomero-Gallagher 2017). Furthermore, it highlights the role that both neurotransmitters play, together with modulatory neurotransmitters, in maintaining the balance between excitation and inhibition essential for a correct functioning of the brain (Markram et al. 2004; Rao et al. 2000; Wehr and Zador 2003; Wu and Sun 2015; Xu et al. 2011).

\section{Parcellation schemes of the SPL}

The parietal cortex has been object of several cytoarchitectonic studies, some of which have provided maps of the entire SPL (Brodmann 1909; Lewis and van Essen 2000; Morecraft et al. 2004; Pandya and Seltzer 1982), whereas others have focussed on specific parts such as the cortex located within the anterior wall of the parieto-occipital sulcus (Colby et al. 1988; Luppino et al. 2005) or the precuneus (Passarelli et al. 2018). Our multivariate analysis confirms the parcellation scheme proposed by Luppino et al. (2005) for the anterior bank of the pos, and the existence of an area PGm in the precuneus (Pandya and Seltzer 1982; Passarelli et al. 2018). We largely confirmed the delineations of Morecraft and colleagues (2004) on the convexity of the SPL and within the cingulate sulcus, but found subdivisions within their area PE. Finally, analysis of the GLI profiles enabled us to revise the identification of cortical layers and sublayers of the SPL areas, and the identification of three sublayers for layer III, and two sublayers for layer V. 

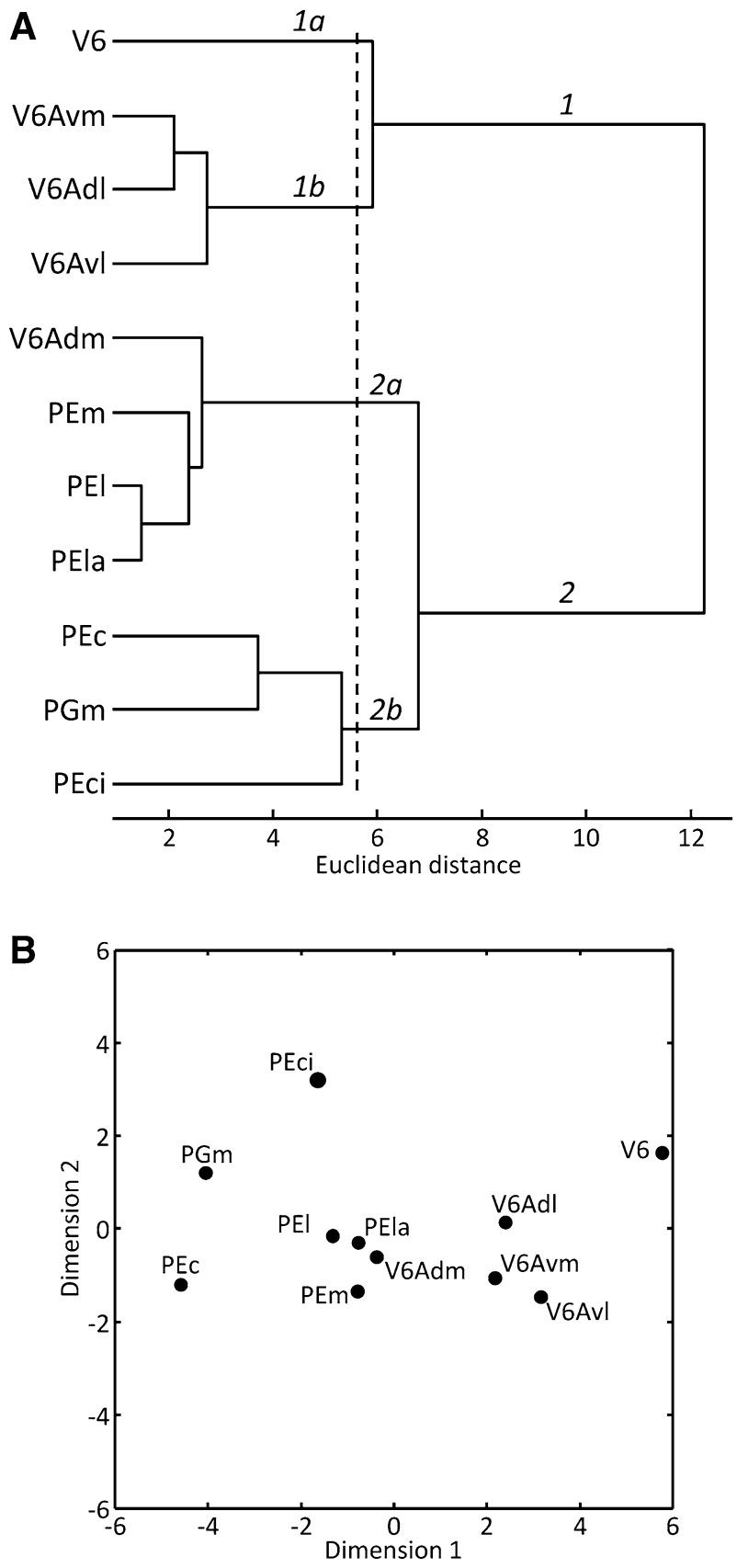

Fig. 16 Hierarchical cluster (a) and multi-dimensional scaling (b) analyses of the mean receptor densities of areas of the SPL

Both the quantitative analysis of cytoarchitectonic features (GLI analysis) and the qualitative and quantitative assessment of the regional and laminar distribution patterns of multiple receptor types corroborated the subdivision of area V6A into dorsal and ventral components in the anterior bank of the pos, as well as the location and extent of area PGm in the precuneus. Furthermore, we found that the medial part of areas V6Av and V6Ad presented a higher receptor density pattern compared to the lateral part, in particular for GABA receptors.
This may be explained by the fact that the medial parts of both areas are involved in further, or different, processes with respect to the medial ones. Specifically, since the precuneate cortex anterior to V6A codifies for complex actions related to spatial navigation, scene perception, and spatial working memory (Baumann and Mattingley 2010; Hutchison et al. 2015; Kravitz et al. 2011; Sato et al. 2006, 2010), it can be suggested that the higher receptor density found in the medial part of areas V6Av and V6Ad could be necessary to encode complex aspect of the visuo-motor integration. Also, it has been recently demonstrated that V6A is active during covertly shifts of spatial attention (Caspari et al. 2015; Galletti et al. 2010). Very recent fMRI experiments show that during attentional shifts two separate foci of activation appear in the medial and lateral parts of macaque V6A (see Fig. 3b of Caspari et al. 2018), suggesting possible different functional role for these two brain regions.

We were also able to confirm the existence of areas PEci, previously described by Morecraft and colleagues (2004), and PE (Pandya and Seltzer 1982). However, while originally Pandya and Seltzer (1982) defined area PE as a cytoarchitectonic homogeneous entity, we have found here three subdivisions within PE. It is worthwhile to notice that recent studies also focussed on connectional characteristics have pointed at possible subdivisions within area PE (Bakola et al. 2013; Gamberini et al. 2017; Impieri et al. 2018), and recent functional studies have also shown that area PE is divided into different somatotopic sectors (see, for example, Seelke et al. 2012). Figure $4 \mathrm{~b}$ shows the three subdivisions of area PE we have found here: area PEl is visible on the exposed surface of the SPL as a relatively thin strip on the rim of the intraparietal sulcus, and continues into the outer portion of the medial bank of the intraparietal sulcus area PEla forms a long strip in front of area PEl, and PEm is a cortical region located dorsomedially. PEla and PEl seem to overlap with the somatotopic map shown by Seelke and coworkers in area 5 [see Fig. 9 of Seelke et al. (2012)], while the region we defined as PEm still needs to be functionally characterized. Connectional studies reported that the lateral part of PE receives preferential input from anterior sectors of the medial bank of intraparietal sulcus and from the ventral premotor cortex, whereas medial part of PE forms denser connections with area PEc and motor fields. In conclusion, both functional and connectional studies support the view of subdivisions within area PE, but further experiments are needed to determine the functional role(s) of these subdivisions.

\section{Receptor-architectonic and functional organization of SPL areas}

Comparing the receptor fingerprints of the SPL areas, a gradual increase in their size, which reflects an increase 
in receptor densities, is appreciable when moving from the fundus of the pos to the exposed surface of the SPL. This increase in receptor density can be associated with differences in the functional characteristics of the areas of the SPL. Visual and somatosensory cells are located in the SPL cortex with a distinctive differentiation depending on the cortical area examined (Gamberini et al. 2011, 2015, 2018; Mountcastle et al. 1975; Seelke et al. 2012). In area V6 all cells are responsive to visual stimuli, while in V6Av and V6Ad only a part of them are visually responsive, while others are responsive to somatosensory stimuli are present (20 and $40 \%$ of the total amount in V6Av and V6Ad, respectively; Gamberini et al. 2011). In area PEc, cells responsive to somatosensory stimuli slightly prevail over those responsive to visual stimuli, reaching $60 \%$ of the total amount (Gamberini et al. 2018). Area PE, instead, represents the somatic counterpart of area V6, in the sense that almost the totality of PE neurons (99\%) are activated by somatosensory or somatomotor stimulations (Mountcastle et al. 1975). No detailed findings on cellular properties are available for areas PEci or PGm. However, from the available studies (Murray and Coulter 1981 for area PEci; Leichnetz 2001; Olson et al. 1996; Passarelli et al. 2018; Thier and Andersen 1998 for area PGm), it is possible to assume that area PEci contains mainly somatosensory neurons, while neurons responding to both visual and somatosensory stimuli can be found in area PGm. Viewed as a whole, two functional streams seem to coexist in the SPL: a visual one, whose intensity decreases moving from the fundus of the pos to the exposed surface of the SPL, and a somatosensory one, whose intensity decreases in the opposite direction. While V6 and PE are unimodal areas, PEc, PGm, and V6Ad, that are central nodes of these two streams, are bimodal visual-somatic areas. PEc and PGm are also the areas with the highest receptor densities of all SPL areas, and V6Ad has the largest fingerprint of all areas located within the pos. We believe that the high receptor density represents an important physiological base for the control of limb movement in reaching and grasping activity. In fact, these activities require a fine and precise integration of visual and somatic stimuli, particularly proprioception and tactile information coming from the limbs, as it is the case in both areas PEc and V6Ad (Gamberini et al. 2018). High receptor densities, particularly of GABAergic and NMDA receptors as shown in the present results, could provide the specific balance of excitatory and inhibitory neurotransmissions needed to control the limb movements during visually guided actions. The bimodal SPL areas PEc and V6Ad (and maybe PGm) located at the interface between somatic and visual system could play a crucial role in the visual guidance of limb movements (Gamberini et al. 2018).

\section{Comparison with the human SPL}

The human SPL encompasses Brodmann's areas 5 and 7 (Brodmann 1909), which are equivalent to area $\mathrm{PA}_{2}$ and areas $\mathrm{PE}_{\mathrm{m}}, \mathrm{PE}_{\mathrm{p}}$ and $\mathrm{PE}_{\gamma}$ of von Economo and Koskinas (1925), respectively. More recent studies applying quantitative cytoand receptor autoradiographic techniques revealed that Brodmann's area 5 is composed of three subdivisions, i.e. 5L, 5M, and $5 \mathrm{Ci}$, whereas his area 7 was divided into 4 parts, i.e. $7 \mathrm{~A}$, 7P, 7PC, 7M (Scheperjans et al. 2005a, b, 2008a, b).

In the light of present results, we suggest that macaque area $\mathrm{PEci}$ corresponds to human area $5 \mathrm{Ci}$, macaque areas PEla and PEl, together, to human area 5L (see above in "Discussion"), and PEm is the homologous of human 5M. As far as Brodmann's area 7 is concerned, it occupies most of the exposed surface of SPL in humans, and has been divided into four cyto- and receptor-architectonically distinct areas (areas 7A, 7P, 7PC, 7M; Scheperjans et al. 2008a). In macaque, on the contrary, area 7 is reported in the mesial surface of the hemisphere (area PGm) and in the IPL (PG, PFG, PF), with a very thin and often disregarded cortical strip in the caudal most part of the exposed surface of SPL. While human area $7 \mathrm{M}$ is likely the homologous of macaque area PGm, for a number of reasons it seems to us unlikely that areas 7A, 7P, 7PC are the homologs to areas PG, PFG, PF. Since we have suggested that area $\mathrm{PEc}$, in the caudal aspect of macaque SPL, is part of area 7 (see above in "Discussion"; Galletti and Gamberini 2018; Gamberini et al. 2017), we believe that the caudal part of human area 7 could be the homologous of macaque area PEc of von Economo and Koskinas (1925). Further studies are needed to verify this hypothesis.

For the areas of the pos, studies in humans that used autoradiographic techniques have not yet reached the same degree of accuracy as in the macaque. So far, several ventral and dorsal parts have been identified within Brodmann's area 19 (e.g. hOc3d, hOc3v, hOc4d, hOc4v; Kujovic et al. 2013; Rottschy et al. 2007) with different receptor-architectonic patterns (Scheperjans et al. 2005b). At the same time, functional studies in human allowed to recognize the homologues of macaque areas V6, V6Av, and V6Ad (Pitzalis et al. 2006, 2013; Tosoni et al. 2015; for a review also see Pitzalis et al. 2015). However, to date, we have no hints to suggest a parallel in the human between the cytoarchitectonically or receptor-based defined areas within Brodmann's area 19 and the functionally defined areas V6, V6Av, and V6Ad. Again, further studies are needed to clarify this point.

\section{Concluding remarks}

The present multivariate analysis of receptor fingerprints confirms the associative role of SPL areas in the encoding of visual and somatosensory stimuli necessary to execute 
reaching and grasping movements (Fattori et al. 2017; Galletti and Fattori 2018; Galletti et al. 2003; Gamberini et al. 2011; Mountcastle et al. 1975; Seelke et al. 2012). Based on differences in cytoarchitecture and laminar receptor distribution patterns, we were able to identify and characterize novel subdivisions of area PE and provide new insights into the functional organization of the macaque SPL. The data reported here support a good homology between macaque and human SPL. Hopefully, future analyses will elucidate whether the ensuing novel parcellation scheme of the SPL has reliable functional counterparts, as suggested here.

Acknowledgements This project has received funding from the European Union's Horizon 2020 Research and Innovation Programme under Grant Agreement No. 785907 (HBP SGA2) and from a Marco Polo Travel Fellowship from the University of Bologna, Department of Pharmacy and Biotechnology.

Funding This project has received funding from the European Union's Horizon 2020 Research and Innovation Programme under Grant Agreement No. 785907 (HBP SGA2) and from a Marco Polo Travel Fellowship from the University of Bologna, Department of Pharmacy and Biotechnology.

\section{Compliance with ethical standards}

Conflict of interest The authors declare that they have no conflict of interest.

Research involving human participants and/or animals All the animals were male specimens between 6 and 8 years old, with a body weight between 5.2 and $6.6 \mathrm{~kg}$, and obtained from Covance Company, Münster, where they were used as control animals for pharmaceutical studies performed in compliance with legal requirements.

Informed consent All authors have read and approved the final version of the manuscript.

Open Access This article is distributed under the terms of the Creative Commons Attribution 4.0 International License (http://creativeco mmons.org/licenses/by/4.0/), which permits unrestricted use, distribution, and reproduction in any medium, provided you give appropriate credit to the original author(s) and the source, provide a link to the Creative Commons license, and indicate if changes were made.

\section{References}

Bakola S, Gamberini M, Passarelli L, Fattori P, Galletti C (2010) Cortical connections of parietal field PEc in the macaque: linking vision and somatic sensation for the control of limb action. Cereb Cortex 20(11):2592-2604

Bakola S, Passarelli L, Gamberini M, Fattori P, Galletti C (2013) Cortical connectivity suggests a role in limb coordination for macaque area PE of the superior parietal cortex. J Neurosci 33(15):6648-6658
Baumann O, Mattingley JB (2010) Medial parietal cortex encodes perceived heading direction in humans. J Neurosci 30(39):12897-12901

Bozkurt A, Zilles K, Schleicher A, Kamper L, Sanz Arigita E, Uylings HBM, Kötter R (2005) Distributions of transmitter receptors in the macaque cingulate cortex. NeuroImage 25:219-229

Breveglieri R, Galletti C, Gamberini M, Passarelli L, Fattori P (2006) Somatosensory cells in area PEc of macaque posterior parietal cortex. J Neurosci 26(14):3679-3684

Breveglieri R, Galletti C, Monaco S, Fattori P (2008) Visual, somatosensory, and bimodal activities in the macaque parietal area PEc. Cereb Cortex 18(4):806-816

Brodmann K (1909) Vergleichende Lokalisationslehre der Großhirnrinde in ihren Prinzipien dargestellt auf Grund des Zellbaues. Barth, Leipzig

Caspari N, Janssens T, Mantini D, Vandenberghe R, Vanduffel W (2015) Covert shifts of spatial attention in the macaque monkey. J Neurosci 35(20):7695-7714

Caspari N, Arsenault JT, Vandenberghe R, Vanduffel W (2018) Functional similarity of medial superior parietal areas for shift-selective attention signals in humans and monkeys. Cereb Cortex 28(6):2085-2099

Colby CL, Gattass R, Olson CR, Gross CG (1988) Topographical organization of cortical afferents to extrastriate visual area PO in the macaque: a dual tracer study. J Comp Neurol 269(3):392-413

Eickhoff SB, Schleicher A, Scheperjans F, Palomero-Gallagher N, Zilles K (2007) Analysis of neurotransmitter receptor distribution patterns in the cerebral cortex. NeuroImage 34(4):1317-1330

Fattori P, Breveglieri R, Bosco A, Gamberini M, Galletti C (2017) Vision for prehension in the medial parietal cortex. Cereb Cortex 27(2):1149-1163

Ferraina S, Garasto MR, Battaglia-Mayer A, Ferraresi P, Johnson PB, Lacquaniti F, Caminiti R (1997) Visual control of handreaching movement: activity in parietal area $7 \mathrm{~m}$. Eur J Neurosci 9(5):1090-1095

Galletti C, Fattori P (2018) The dorsal visual stream revisited: stable circuits or dynamic pathways? Cortex 98:203-217

Galletti C, Gamberini M (2018) Superior parietal lobule (SPL). In: Vonk J, Shackelford T (eds) Encyclopedia of animal cognition and behavior. Springer, Cham. https://doi.org/10.1007/978-3-31947829-6_489-1

Galletti C, Fattori P, Gamberini M, Kutz DF (1999a) The cortical visual area V6: brain location and visual topography. Eur J Neurosci 11:3922-3936

Galletti C, Fattori P, Kutz DF, Gamberini M (1999b) Brain location and visual topography of cortical area V6A in the macaque monkey. Eur J Neurosci 11:575-582

Galletti C, Gamberini M, Kutz DF, Fattori P, Luppino G, Matelli M (2001) The cortical connections of area V6: an occipitoparietal network processing visual information. Eur J Neurosci 13:1572-1588

Galletti C, Kutz DF, Gamberini M, Breveglieri R, Fattori P (2003) Role of the medial parieto-occipital cortex in the control of reaching and grasping movements. Exp Brain Res 153:158-170

Galletti C, Breveglieri R, Lappe M, Bosco A, Ciavarro M, Fattori P (2010) Covert shift of attention modulates the ongoing neural activity in a reaching area of the macaque dorsomedial visual stream. PLoS One 5(11):e15078

Gallyas F (1979) Silver staining of myelin by means of physical development. Neurol Res 1(2):203-209

Gamberini M, Passarelli L, Fattori P, Zucchelli M, Bakola S, Luppino G, Galletti C (2009) Cortical connections of the visuomotor parietooccipital area V6Ad of the macaque monkey. J Comp Neurol 513(6):622-642 
Gamberini M, Galletti C, Bosco A, Breveglieri R, Fattori P (2011) Is the medial posterior parietal area V6A a single functional area? J Neurosci 31(13):5145-5157

Gamberini M, Fattori P, Galletti C (2015) The medial parietal occipital areas in the macaque monkey. Vis Neurosci 32:E013

Gamberini M, Passarelli L, Bakola S, Impieri D, Fattori P, Rosa MG, Galletti C (2017) Claustral afferents of superior parietal areas PEc and PE in the macaque. J Comp Neurol 525(6):1475-1488

Gamberini M, Dal BG, Breveglieri R, Briganti S, Passarelli L, Fattori P, Galletti C (2018) Sensory properties of the caudal aspect of the macaque's superior parietal lobule. Brain Struct Funct 223(4):1863-1879

Goodale MA, Milner AD (1992) Separate visual pathways for perception and action. Trends Neurosci 15(1):20-25

Hutchison RM, Culham JC, Flanagan JR, Everling S, Gallivan JP (2015) Functional subdivisions of medial parieto-occipital cortex in humans and nonhuman primates using resting-state fMRI. NeuroImage 116:10-29

Impieri D, Gamberini M, Passarelli L, Rosa MGP, Galletti C (2018) Thalamo-cortical projections to the macaque superior parietal lobule areas PEc and PE. J Comp Neurol 526(6):1041-1056

Kravitz DJ, Saleem KS, Baker CI, Mishkin M (2011) A new neural framework for visuospatial processing. Nat Rev Neurosci 12(4):217-230

Kujovic M, Zilles K, Malikovic A, Schleicher A, Mohlberg H, Rottschy C, Eickhoff SB, Amunts K (2013) Cytoarchitectonic mapping of the human dorsal extrastriate cortex. Brain Struct Funct 218(1):157-172

Leichnetz GR (2001) Connections of the medial posterior parietal cortex (area 7m) in the monkey. Anat Rec 263(2):215-236

Lewis JW, van Essen DC (2000) Mapping the architectonic subdivisions in the macaque monkey, with emphasis on parieto-occipital cortex. J Comp Neurol 428:79-111

Luppino G, Ben Hamed S, Gamberini M, Matelli M, Galletti C (2005) Occipital (V6) and parietal (V6A) areas in the anterior wall of the parieto-occipital sulcus of the macaque: a cytoarchitectonic study. Eur J Neurosci 21:3056-3076

Mahalanobis PC, Majumda DN, Rao CR (1949) Antropometric survey of the united provinces. A statistical study. Sankhya 9:89-324

Markram H, Toledo-Rodriguez M, Wang Y, Gupta A, Silberberg G, Wu C (2004) Interneurons of the neocortical inhibitory system. Nat Rev Neurosci 5(10):793-807

Merker B (1983) Silver staining of cell bodies by means of physical development. J Neurosci Methods 9:235-241

Morecraft RJ, Cipolloni PB, Stilwell-Morecraft KS, Gedney MT, Pandya DN (2004) Cytoarchitecture and cortical connections of the posterior cingulate and adjacent somatosensory fields in the rhesus monkey. J Comp Neurol 469:37-69

Mountcastle VB, Lynch JC, Georgopoulos A, Sakata H, Acuna C (1975) Posterior parietal association cortex of the monkey: command functions for operations within extrapersonal space. J Neurophysiol 38(4):871-908

Murray EA, Coulter JD (1981) Organization of corticospinal neurons in the monkey. J Comp Neurol 195:339-365

Olson CR, Musil SY, Goldberg ME (1996) Single neurons in posterior cingulate cortex of behaving macaque: eye movement signals. $\mathrm{J}$ Neurophysiol 76(5):3285-3300

Padberg J, Franca JG, Cooke DF, Soares JG, Rosa MG, Fiorani M Jr, Gattass R, Krubitzer L (2007) Parallel evolution of cortical areas involved in skilled hand use. J Neurosci 27(38):10106-10115

Palomero-Gallagher N, Zilles K (2018) Cyto- and receptorarchitectonic mapping of the human brain. Handb Clin Neurol 150:355-387

Palomero-Gallagher N, Vogt BA, Schleicher A, Mayberg HS, Schleicher A, Zilles K (2009) Receptor architecture of human cingulate cortex: evaluation of the four-region neurobiological model. Hum Brain Mapp 30(8):2336-2355
Palomero-Gallagher N, Zilles K, Schleicher A, Vogt BA (2013) Cytoand receptor architecture of area 32 in human and macaque brains. J Comp Neurol 521(14):3272-3286

Pandya DN, Seltzer B (1982) Intrinsic connections and architectonics of posterior parietal cortex in the rhesus monkey. J Comp Neurol 204(2):196-210

Passarelli L, Rosa MG, Gamberini M, Bakola S, Burman KJ, Fattori P, Galletti C (2011) Cortical connections of area V6Av in the macaque: a visual-input node to the eye/hand coordination system. J Neurosci 31(5):1790-1801

Passarelli L, Rosa MGP, Bakola S, Gamberini M, Worthy KH, Fattori P, Galletti C (2018) Uniformity and diversity of cortical projections to precuneate areas in the macaque monkey: what defines area PGm? Cereb Cortex 28(5):1700-1717

Piserchia V, Breveglieri R, Hadjidimitrakis K, Bertozzi F, Galletti C, Fattori P (2017) Mixed body/hand reference frame for reaching in 3D space in macaque parietal area PEc. Cereb Cortex 27(3):1976-1990

Pitzalis S, Galletti C, Huang RS, Patria F, Committeri G, Galati G, Fattori P, Sereno MI (2006) Wide-field retinotopy defines human cortical visual area v6. J Neurosci 26(30):7962-7973

Pitzalis S, Sereno MI, Committeri G, Fattori P, Galati G, Tosoni A, Galletti C (2013) The human homologue of macaque area V6A. NeuroImage 82:517-530

Pitzalis S, Fattori P, Galletti C (2015) The human cortical areas V6 and V6A. Vis Neurosci 32:E007

Rao SG, Williams GV, Goldman-Rakic PS (2000) Destruction and creation of spatial tuning by disinhibition: $\mathrm{GABA}_{\mathrm{A}}$ blockade of prefrontal cortical neurons engaged by working memory. $\mathrm{J}$ Neurosci 20(1):485-494

Rizzolatti G, Matelli M (2003) Two different streams form the dorsal visual system: anatomy and functions. Exp Brain Res 153:146-157

Rottschy C, Eickhoff SB, Schleicher A, Mohlberg H, Kujovic M, Zilles K, Amunts K (2007) Ventral visual cortex in humans: cytoarchitectonic mapping of two extrastriate areas. Hum Brain Mapp 28:1045-1059

Rousseeuw PJ (1987) Silhouettes: a graphical aid to the interpretation and validation of cluster analysis. J Comput Appl Math 20:53-65

Sato N, Sakata H, Tanaka YL, Taira M (2006) Navigation-associated medial parietal neurons in monkeys. Proc Natl Acad Sci USA 103(45):17001-17006

Sato N, Sakata H, Tanaka YL, Taira M (2010) Context-dependent place-selective responses of the neurons in the medial parietal region of macaque monkeys. Cereb Cortex 20(4):846-858

Scheperjans F, Grefkes C, Palomero-Gallagher N, Schleicher A, Zilles K (2005a) Subdivisions of human parietal area 5 revealed by quantitative receptor autoradiography: a parietal region between motor, somatosensory and cingulate cortical areas. NeuroImage 25:975-992

Scheperjans F, Palomero-Gallagher N, Grefkes C, Schleicher A, Zilles K (2005b) Transmitter receptors reveal segregation of cortical areas in the human superior parietal cortex: relations to visual and somatosensory regions. NeuroImage 28:362-379

Scheperjans F, Eickhoff SB, Homke L, Mohlberg H, Hermann K, Amunts K, Zilles K (2008a) Probabilistic maps, morphometry, and variability of cytoarchitectonic areas in the human superior parietal cortex. Cereb Cortex 18(9):2141-2157

Scheperjans F, Hermann K, Eickhoff SB, Amunts K, Schleicher A, Zilles K (2008b) Observer-independent cytoarchitectonic mapping of the human superior parietal cortex. Cereb Cortex 18(4):846-867

Seelke AM, Padberg JJ, Disbrow E, Purnell SM, Recanzone G, Krubitzer L (2012) Topographic maps within Brodmann's area 5 of macaque monkeys. Cereb Cortex 22(8):1834-1850 
Thier P, Andersen RA (1998) Electrical microstimulation distinguishes distinct saccade-related areas in the posterior parietal cortex. J Neurophysiol 80(4):1713-1735

Tosoni A, Pitzalis S, Committeri G, Fattori P, Galletti C, Galati G (2015) Resting-state connectivity and functional specialization in human medial parieto-occipital cortex. Brain Struct Funct 220(6):3307-3321

von Economo C, Koskinas GN (1925) Die Cytoarchitektonik der Hirnrinde des erwachsenen Menschen. Springer, Wien

Wehr M, Zador AM (2003) Balanced inhibition underlies tuning and sharpens spike timing in auditory cortex. Nature 426:442-446

Wree A, Schleicher A, Zilles K (1982) Estimation of volume fractions in nervous tissue with an image analyzer. J Neurosci Methods 6(1-2):29-43

Wu C, Sun D (2015) GABA receptors in brain development, function, and injury. Metab Brain Dis 30(2):367-379

Xu G, Broadbelt KG, Haynes RL, Folkerth RD, Borenstein NS, Belliveau RA, Trachtenberg FL, Volpe JJ, Kinney HC (2011) Late development of the GABAergic system in the human cerebral cortex and white matter. J Neuropathol Exp Neurol 70(10):841-858

Zilles K, Palomero-Gallagher N (2017) Comparative analysis of receptor types that identify primary cortical sensory areas. In: Kaas JH (ed) Evolution of nervous systems, 2nd edn. Elsevier, Oxford, pp 225-245

Zilles K, Schleicher A, Palomero-Gallagher N, Amunts K (2002) Quantitative analysis of cyto- and receptorarchitecture of the human brain. In: Toga AW, Mazziotta JC (eds) Brain mapping. The methods, 2nd edn. Elsevier, Amsterdam, pp 573-602

Publisher's Note Springer Nature remains neutral with regard to jurisdictional claims in published maps and institutional affiliations. 